\title{
Proses Pembelajaran \\ (Learning Lessons) Promosi Sertifikasi \\ Hutan dan Pengendalian Penebangan Liar di Indonesia
}

September 2003 sampai Juni 2006

Emile Jurgens

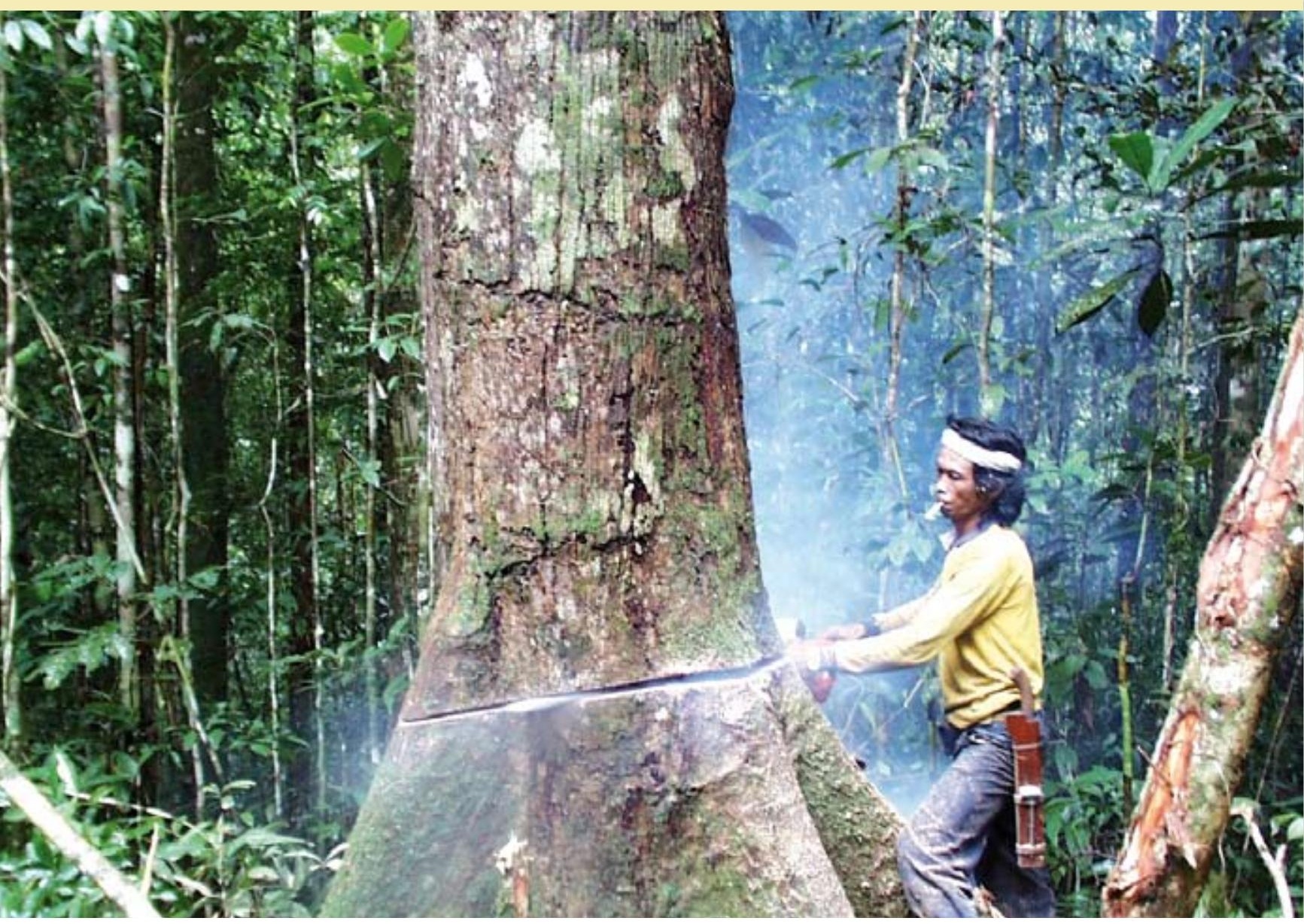

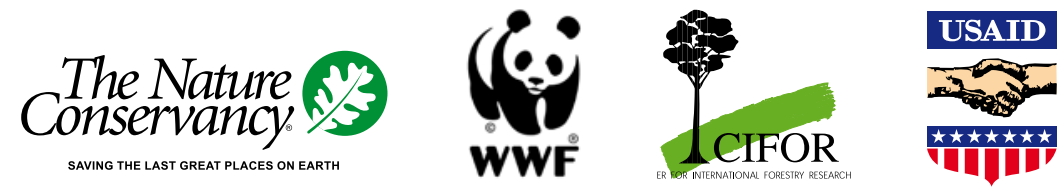




\section{Proses Pembelajaran (Learning Lessons) Promosi Sertifikasi Hutan dan Pengendalian Penebangan Liar di Indonesia}

September 2003 sampai Juni 2006

Emile Jurgens 
Perpustakaan Nasional Indonesia, Penerbitan dalam Katalog (KDT)

Proses Pembelajaran (Learning Lessons) Promosi Sertifikasi Hutan dan Pengendalian Penebangan Liar di Indonesia: September 2003 sampai Juni 2006/oleh Emile Jurgens. Bogor, Indonesia: Center for International Forestry Research, 2006.

ISBN 979-24-4661-3

$57 \mathrm{p}$.

$\mathrm{CABI}$ thesaurus: 1 . certification 2 . timbers 3 . forest products 4 . supply balance 5 . markets 6. linkage 7. 8. timber trade 9. logging 10. Indonesia I. Title

๑ 2006 oleh Center for International Forestry Research

Hak cipta dilindungi undang-undang

Dicetak oleh Harapan Prima, Jakarta

Desian cover dan tata letak oleh Gideon Suharyanto

Foto sampul oleh Agung Prasetyo

Diterbitkan oleh

Center for International Forestry Research

Alamat surat: P.O. Box 6596 JKPWB, Jakarta 10065, Indonesia

Alamat kantor: Jl. CIFOR, Situ Gede, Sindang Barang, Bogor Barat 16680, Indonesia

Tel.: +62 (251) 622622; Fax: +62 (251) 622100

Email: cifor@cgiar.org

Situs web: http://www.cifor.cgiar.org 


\section{Daftar Isi}

1. Pendahuluan 1

2. Gambaran Umum Kemajuan Aliansi dari September 2003 sampai dengan April 2006

2.1 Penguatan sinyal pasar untuk produksi kayu bersertifikat dan verifikasi kayu legal 5

2.1.1 Keberlanjutan kerjasama dengan pembeli kayu 5

2.1.2 Penggalangan hubungan sektor publik di Pasar Asia $\quad 7$

2.2 Peningkatan ketersediaan produk kayu Indonesia yang bersertifikat

2.2.1 Peresmian jaringan kehutanan dan perdagangan (FTN) Indonesia

2.2.2 Dukungan sertifikasi hutan di Indonesia 10

2.2.3 Promosi pemahaman dari sertifikasi hutan dan isu pembalakan liar

2.3 Peragaan solusi praktis untuk mencapai sertifikasi dan membedakan sumber kayu legal dan ilegal $\quad 11$
2.3.1 Definisi "Legal"

2.3.2 Pengembangan verifikasi legalitas independen dan sistem lacak balak

2.3.3 Dukungan perlindungan pada Hutan dengan Nilai Konservasi Tinggi (HCVF) 14

2.3.4 Dukungan terhadap manajemen kolaborasi di SLJ IV 15

2.4 Pengurangan dukungan finansial dan investasi pada perusahaan yang terlibat dalam perusakan hutan dan pembalakan liar $\quad 16$

2.4.1 Kerjasama dengan bank untuk memperbaiki asesmen resiko lingkungan dan sosial 16

2.4.2 Pengaruh pada Kreditor Asia Pulp dan Paper 16

3. Pembelajaran Keterkaitan Kebutuhan akan Produk Kayu yang Lestari dengan Penyediaannya dari Indonesia

3.1 Kebutuhan produk kayu yang lestari di pasar tempat

Aliansi bekerja

3.1.1 Uni Eropa

3.1.2 Amerika Serikat 
$\begin{array}{ll}3.1 .3 \text { Jepang } & 23\end{array}$

$\begin{array}{ll}3.1 .4 \text { Cina } & 24\end{array}$

3.2 Pembelajaran kondisi permintaan terhadap produk kayu yang lestari dari Indonesia $\quad 27$

3.3 Hubungan permintaan dan penawaran 28

3.3.1 Pengiriman sinyal pasar ke perusahaan pengelolaan hutan 28

3.3.2 Insentif untuk perusahaan-perusahaan Indonesia 31

3.4 Pembelajaran pada ketersediaan produk kayu yang lestari dari Indonesia 34

4. Pembelajaran dalam Promosi Verifikasi Kayu Legal 38

4.1 Penentuan 'Kayu Legal' 38

4.1.1 Inggris-RI MoU standar legalitas $\quad 39$

4.1.2 Manual "Penetapan legalitas" dari WWF $\quad 41$

4.2 Pembelajaran dari penentuan kayu "Legal” 43

5. Pembelajaran Umum 46

6. Rekomendasi 54

$\begin{array}{ll}\text { Bibliografi } & 56\end{array}$ 


\section{Daftar Akronim dan Singkatan}

APKINDO Asosiasi Panel Kayu Indonesia or Indonesian Plywood Association

BRIK Badan Revitalizasi Industri Kehutanan or Forest Industry

Revitalization Body

BSW $\quad$ PT Bangun Sarana Wreksa

CAR Corrective Action Request

CIFOR Center for International Forestry Research

CITES Convention on International Trade in Endangered Species

$\mathrm{CoC} \quad$ Chain of Custody

FLEG Forest Law Enforcement and Governance

FM Forest Management

FMU Forest Management Unit

FPIC Free prior and informed consent

FSC Forest Stewardship Council

FTN Forest and Trade Network

GFTN Global Forest and Trade Network

GoI Government of Indonesia

HCVF High Conservation Value Forest

LEI Lembaga Ekolabel Indonesia or Indonesian Ecolabelling Institute

LKS Lesser-known species

MoF Ministry of Forestry

$\mathrm{MoU} \quad$ Memorandum of Understanding

MTH Mixed tropical hardwood

NGO Non-Governmental Organization

DRT PT Diamond Raya Timber

DIY Do It Yourself

RKT Rencana Karya Tahunan or Annual Work Plan

RST Rough sawn timber

RWE Roundwood equivalent

SFM Sustainable Forest Management

SPWP Secondary Processed Wood Products

SLJ PT Sumalindo Lestari Jaya

TFT Tropical Forest Trust 
TNC The Nature Conservancy

TPTI Tebang Pilih dan Tanam Indonesia or Indonesian Selective Cutting and Planting system

TTF UK Timber Trade Federation

VPA Voluntary Partnership Agreement

VVNH The Dutch Timber Trading Association

WALHI Wahana Alam dan Lingkungan Hidup or The Indonesian Forum for the Environment

WWF World Wide Fund for Nature 


\section{Pendahuluan}

Aliansi Pembangunan Global (Aliansi) dalam mempromosikan Sertifikasi Hutan dan Pemberantasan Pembalakan Liar di Indonesia telah mencapai perkembangan yang berarti sejak Proses Pembelajaran pertama yang diterbitkan oleh CIFOR pada tahun 2003. Hasil penting yang dicapai antara September 2003 dan Maret 2006 adalah sebagai berikut:

- Rancangan standar legalitas produk kayu untuk Indonesia.

- Keberhasilan uji coba dari verifikasi legalitas yang independen dan mekanisme lacak balak.

- Peningkatan kesadaran serta kebutuhan pendekatan secara regional untuk pemberantasan pembalakan liar.

- Penetapan Jaringan Perdagangan Kayu (Forest and Trade Network) di Indonesia dan Cina serta rekruitmen anggota dari perusahaan kehutanan, pedagang serta produsen kayu.

- Pembangunan sebuah model pengelolaan hutan kolaborasi antara masyarakat tempatan dan perusahaan kehutanan di Kalimantan Timur.

- Pengintegrasian hutan dengan nilai konservasi tinggi (HCVF) ke dalam Rencana Tata Ruang Propinsi Kalimantan Timur.

- Persetujuan pada kriteria untuk produksi kelapa sawit secara Lestari.

- Sertifikat Pengelolaan Hutan Lestari dari FSC pada areal seluas 270.000 ha di Hak Pengusahaan Hutan (HPH) di Kalimantan Timur, yang merupakan hutan bersertifikat terbesar dari FSC di seluruh kawasan Asia Tenggara.

- Sertifikat Lembaga Ekolabel Indonesia yang pertama untuk hutan rakyat di Indonesia.

- Penerimaan dari kebijakan pembelian dari pengguna utama di Jepang.

Kemajuan-kemajuan kegiatan tersebut telah dicapai pada situasi yang sulit dan aktivitas Aliansi telah membawa sebuah pembelajaran dan pengalaman penting tentang kehutanan di Indonesia dan kesempatan serta tantangan untuk membenahinya. Sektor ini dicirikan oleh lemahnya tata kelola (governance) serta kondisi finansial yang tidak mendukung. Kondisi yang tidak menentu ini berhadapan dengan sebuah kendala yang substansial untuk perubahan yang 
positif tetapi juga memberikan kondisi pemungkin (enabling condition) bagi proses pembelajaran. Para Mitra dari Aliansi saat ini terus melakukan pembelajaran dan pada beberapa kasus telah mengadaptasi untuk keperluan pendekatan kegiatan mereka.

Pengalaman Aliansi telah menunjukkan bahwa keterkaitan para pembeli potensial dan produsen kayu yang berasal dari hutan yang lestari di Indonesia, dengan sendirinya, tidaklah cukup untuk membawa suatu perubahan yang cepat dan besar seperti yang diharapkan pada rencana awal Aliansi. Pada masa tiga tahun pertama Aliansi telah mengadaptasi pendekatan dengan memfokuskan kegiatan pada keterkaitan pasar menuju pendekatan yang lebih luas pada peningkatan kondisi pemungkin (enabling condition) dan promosi kebijakan publik yang terkait dengan insentif bagi kegiatan pengelolaan hutan lestari. Peningkatan stabilitas nasional seiring dengan perubahan pemerintahan pada tahun 2004 yang mengarah pada peningkatan iklim politik dan investasi, yang memberi kesempatan lebih baik bagi Aliansi untuk memerangi pembalakan liar dan perbaikan manajemen hutan di Indonesia.

Pembelajaran tentang situasi pemenuhan dan permintaan kayu dari sumber yang lestari dan kayu hasil verifikasi legalitas adalah:

- Permintaan pasar untuk kayu bersertifikat dan produk kayu legal didorong oleh berbagai faktor termasuk kebijakan pembelian dari perusahaan dan pengaturan kebijakan dari negara pengimpor.

- Para pembeli, mencari kayu yang berasal dari sumber yang legal atau lestari yang juga dapat juga beralih pada supplier kayu yang memiliki resiko lebih rendah, atau memberikan tekanan pada para supplier untuk mencapai sertifikasi atau verifikasi legalitas.

- Perusahaan-perusahaan di Indonesia memiliki kemungkinan kecil untuk merespon permintaan dari para pembeli yang bukan mitra bisnisnya, karena permasalahan pembiayaan dan resiko terkait dengan perubahan orientasi pasar dan keuntungan yang belum jelas.

- Keinginan para pembeli (buyer) untuk kayu legal dan lestari seringkali "tidak terinformasikan dengan baik." oleh konsumen akhir (end consumer) dari rantai pasokan melalui perantara kepada sumber HPH.

- Lemahnya tata kelola hutan berperan sebagai sebuah halangan untuk berinvestasi secara SFM (sustainable forest management) di Indonesia.

- Peran pemerintah dalam verifikasi legalitas kayu sangat penting karena pemerintah adalah pemegang otoritas tertinggi dalam legalitas. Namun 
hal ini juga menjadi problematik, sepertinya pihak-pihak yang mencari verifikasi umumnya telah kehilangan kepercayaan pada sistem yang telah dibuat oleh pemerintah.

- Legalitas harus ditujukan sebagai salah satu rangkaian dari konsep yang luas dari kehutanan yang bertanggung jawab dan proses pembelian kayu.

- Beberapa kebijakan pemerintah telah menjadi halangan yang serius atau dis-insentif bagi perusahaan yang tergabung dalam program pencapaian pengelolaan hutan lestari (SFM).

- Permintaan untuk produk SFM tidak secara langsung merupakan sebuah kesadaran untuk membayar biaya tambahan untuk produksi yang SFM.

- Untuk sertifikasi agar memiliki sebuah pengaruh pada manajemen hutan alam diperlukan penerimaan yang lebih besar dari konsep pendekatan bertahap (stepwise approach).

- Para pembeli yang sensitif terhadap lingkungan umumnya memiliki perhatian yang besar terhadap citra perusahaan mereka dan memerlukan jaminan bahwa produk yang mereka beli diakui statusnya oleh para LSM di pasar dalam negeri mereka.

- Kerjasama multilateral, pendekatan pasar, dan tata kelola yang baik memiliki peran penting dalam memerangi perdagangan kayu illegal.

- Mekanisme berbasis pasar memerlukan aksi konkret secara menyeluruh untuk mencapai sukses.

- Dalam setiap peningkatan kondisi politik dan bisnis, usaha berbasis pasar diawali untuk membantu meningkatkan kondisi pengelolaan hutan di Indonesia.

Aliansi telah merespon segala kompleksitas dan tantangan yang ada dengan memfokuskan pada peningkatan kondisi pemungkin (enabling condition) yang diperlukan untuk dapat merealisasikan manfaat penuh dari keterkaitan pasar. Pada saat keterkaitan antar perusahaan terus menjadi komponen penting dari program ini, Aliansi bekerja lebih dekat pada tingkat kebijakan di Indonesia dan pasar impor untuk menciptakan sebuah peningkatan kebijakan dan kerangka kerja untuk SFM di Indonesia. Kerangka kerja ini berubah menuju kondisi yang lebih baik dan hal ini kemungkinan akan menciptakan sebuah kondisi dimana keterkaitan pasar akan memainkan peran penting yang semakin meningkat.

Sementara itu terdapat beberapa contoh pembelajaran dari aspek kelembagaan yang dapat diambil dari kegiatan Aliansi selama periode berlangsung. Laporan ini memfokuskan pada dua topik besar: 1) Fasilitasi keterkaitan pasar untuk 
menciptakan insentif bagi produser kayu di Indonesia untuk berinvestasi dalam SFM; 2) Pendefinisian "kayu legal" dalam konteks Indonesia. Laporan ini disusun dengan berdasarkan pada informasi yang disediakan oleh mitra Aliansi dan para pihak (stakeholder) melalui wawancara dan komentar tertulis dari September 2005 sampai April 2006 dan juga hasil ulasan dari beberapa literatur mengenai jaringan pasar, sertifikasi, verifikasi legalitas, perdagangan kayu, dan lacak balak. Bagian ke dua dari laporan ini menjelaskan tinjauan umum dari aktivitas Aliansi dalam periode antara September 2003 dan April 2006. Bagian ini dibagi ke dalam empat Bab yang terkait dengan empat dari lima area aktivitas dimana Aliansi terlibat secara aktif:

I. Penguatan sinyal pasar;

II. Peningkatan persediaan produk kayu Indonesia yang bersertifikat;

III. Peragaan solusi praktis untuk mencapai sertifikasi serta membedakan penyediaan kayu legal dan Ilegal; dan

IV. Pengurangan finansial dan investasi pada perusahaan-perusahaan yang terkait dengan kerusakan atau pembalakan liar di Indonesia. ${ }^{1}$

Bagian tiga dan empat dari Laporan ini secara berurutan menjelaskan mengenai fasilitasi jaringan pasar dan penentuan legalitas. Topik-topik ini menjelaskan secara rinci dengan berdasarkan aktivitas Aliansi sebagai latar belakang. Bagian tiga memiliki dua sub bagian. Sub bagian pertama menggabarkan secara rinci mengenai latar belakang permintaan akan produk kayu bersertifikat dan terverifikasi legal di pasar impor tempat Aliansi bekerja (Eropa, USA, Cina dan Jepang). Sub bagian kedua melihat tentang dampak dari permintaan tersebut terhadap sektor kehutanan di Indonesia dan rincian mengenai hambatan yang menghalangi sinyal pasar dalam penyediaan produk kayu Indonesia yang bersertifikasi dan terverifikasi legal. Pembelajaran dari topik-topik yang dihasilkan dari hasil kegiatan Aliansi disajikan secara rinci pada bagian selanjutnya.

Bagian lima menyajikan pembelajaran umum bahwa kegiatan Aliansi telah membawa suatu harapan baru. Laporan ini dilengkapi dengan rekomendasi yang bertujuan untuk menginformasikan kegiatan Aliansi dan kepada aktor-aktor lainnya yang berkeinginan untuk meningkatkan praktek pengelolaan hutan di Indonesia.

\footnotetext{
1 Aktivitas kelima dari kegiatan aliansi ini adalah" Berbagi Pengalaman" (Sharing Lessons Learned). Laporan ini adalah salah satu dari beberapa sumbangan pada area aktivitas tersebut.
} 


\section{Gambaran Umum Kemajuan Aliansi dari September 2003 sampai dengan April 2006}

\subsection{Penguatan sinyal pasar untuk produksi kayu bersertifikat dan verifikasi kayu legal}

\subsubsection{Keberlanjutan kerja sama dengan pembeli kayu}

Pada September 2003 sampai April 2006, Aliansi memperluas kerjasama dengan perusahaan yang berpotensi untuk meningkatkan tingkat permintaan kayu bersertifikat dan kayu legal dari Indonesia. WWF bersama TNC secara terusmenerus membina hubungan baik dengan pembeli kayu di Asia, Eropa, dan Amerika Utara. Mitra-mitra Aliansi menggandeng beberapa perusahaan strategis dari Jepang yang terkait erat dengan sektor kehutanan di Indonesia yaitu Itochu dan Sumitomo Forestry. Perusahaan tersebut telah menyatakan dukungan kuat pada konsep aktivitas Aliansi dan mengindikasikan harapan mereka dalam hal perdagangan kayu dengan Indonesia, terutama untuk produk-produk yang berasal dari hutan yang lestari dan kegiatan kehutanan yang legal. WWF memelihara hubungan baiknya dengan pembeli global dan kreditor dari dua perusahaan pulp dan kertas terbesar di Indonesia, APP dan APRIL, sebagai upaya untuk membantu mereka dalam evaluasi kegiatan dalam perusahaan tersebut. Aliansi telah mencapai perkembangan yang berarti dalam menggalang kerjasama dengan sektor swasta melalui perluasan Jaringan Perdagangan Kehutanan Global (GFTN) - WWF, serta melalui promosi yang sukses dari kebijakan pembelian kertas secara lestari di Jepang.

\section{Perluasan Global Forest Trade Network (GFTN-WWF)}

GFTN-WWF telah berkembang dan saat ini FTN telah ada di negara-negara yang mayoritas adalah pengimpor kayu dari Indonesia, termasuk Cina, Jerman, UK dan USA.

- WWF membentuk FTN Amerika Utara di tahun 2005, dan telah mendaftar empat partisipan dengan komitmen untuk membeli kayu dari sumber 
yang bertanggung jawab - Blue Link (distributor terbesar dari produk bangunan di USA), Johnson and Johnson, TBM hardwoods (salah satu importir terbesar kayu tropis di USA) dan Wood Flooring International.

Pada beberapa tahun yang lalu, GFTN-WWF telah membentuk jaringan yang kuat di Asia Pacifik. Sampai dengan Juni 2006, kemajuan yang telah dicapai terkait dengan hal ini adalah sebagai berikut:

- Pembentukan FTN-Cina memiliki dua unit manajemen hutan dan enam partisipan dari perdagangan kayu (pemrosesan, industri, pedagang dan pengguna akhir). Selain itu enam industri juga telah mengajukan aplikasi untuk bergabung dan saat ini sedang mengembangkan rencana kerja pembelian yang bertanggung jawab sebagai persyaratan keanggotaan.

- FTN-Indonesia memiliki empat anggota manajemen hutan (HPH) dan enam anggota industri dan penjual produk kayu, disamping antrian calon anggota FTN yang terdiri dari tujuh unit manajemen hutan, enam hutan rakyat serta delapan industri dan pemrosesan kayu. Pada Februari 2006, PT. Sumalindo Lestari Jaya II menjadi unit manajemen ( $\mathrm{HPH})$ pertama yang menjadi anggota FTN. PT. Perhutani, Badan Usaha Milik Negara, menandatangani persetujuan menjadi anggota FTN Nusa Hijau untuk lima dari 52 Kesatuan Pemangkuan Hutan $(\mathrm{KPH})$ yang ada. Lima KPH tersebut semuanya terletak di Jawa Timur dengan luasan lebih dari 167.000 hektar.

- Di Jepang, WWF Sanshoukai, memiliki 27 anggota.

- FTN-Malaysia memiliki tiga anggota dari pedagang kayu dan sembilan calon anggota (tujuh pedagang dan dua unit manajemen).

- FTN Vietnam diresmikan pada 4 Oktober 2005, dan sejak itu telah merekrut empat industri kayu sebagai anggota penuh dan empat lainnya sedang menunggu proses keanggotaan.

GFTN berupaya terus untuk melacak sinyal dari anggota pembeli. Sampai Juli 2006, GFTN telah menghasilkan lebih dari 270 permintaan pasar (pesanan potensial dari produk khusus yang menggunakan sumber kayu dari anggota FTN dan hutan bersertifikat) dari anggota perdagangan FTN pada 18 negara penghasil. Total dari permintaan tersebut bernilai US \$ 277 juta untuk para produsen. Diperkirakan 25 persen dari permintaan pembelian ini secara khusus ditujukan pada penghasil kayu di Indonesia atau produk-produk yang dapat diproduksi oleh produsen di Indonesia. Indonesia telah menerima 49 permintaan pembelian dari delapan negara (terbentang dari Eropa dan Amerika Utara ditambah Vietnam) 
dengan perkiraan total nilai lebih dari US \$ 73 Juta. Dari permintaan pembelian tersebut, 20 telah berkembang dalam keterkaitan pasar (hubungan dagang) antara pembeli di Perancis, Jerman, Belanda, Swedia, Swiss, UK, dan USA dengan anggota penghasil di FTN Indonesia.

GFTN WWF juga mempublikasikan Panduan untuk Pembelian yang Bertanggung jawab dari Produk Hutan. Panduan ini memberikan penjelasan terinci sehingga perusahaan termasuk industri hulu, industri semi hilir (sekunder), importir, industri perakit, agen, dan pengecer, dapat merujuk dan menyesuaikan kinerjanya dengan praktek-praktek yang baik dan pada akhirnya terkait dengan kebijakan pembeliannya. ${ }^{2}$ WWF telah menerjemahkan panduan ini ke dalam bahasa Indonesia, Cina, Jepang. Sebuah seminar untuk menyajikan panduan ini di Jepang telah menarik minat sekitar 100 perwakilan perusahaan.

\section{Promosi Pembelian Kertas SFM di Jepang}

WWF telah membantu dua perusahaan raksasa di Jepang, Ricoh and ASKUL, untuk mengadopsi kebijakan pembelian kertas SFM. WWF Jepang secara langsung membantu Ricoh (salah satu produsen produk perkantoran terbesar) dan ASKUL (Pemasok utama untuk keperluan kantor di Jepang) untuk membuat rancangan kebijakan. Ricoh berhenti membeli kertas kopi dari Indonesia didasarkan pada tanggung jawab kebijakan pembelian. Selain perusahaan tersebut terdapat perusahaan lain yang melakukan hal serupa yaitu - Canon Sales Co, Inc, Fuji Xerox Co, Ltd, Fuji Xerox office supply, Oji Paper, Nippon Paper dan Mitsubishi Paper Mills Ltd.

WWF Jepang, Friend of the Earth Jepang, Greenpeace Jepang, Jepang Tropical Forest Action Network (JATAN) dan Global Environmental Forum meresmikan sebuah proyek yang bertujuan "Promosi Pembelian Kertas yang bertanggung jawab di Jepang”. Proyek ini bertujuan untuk menciptakan sebuah kelompok kajian informal perusahaan pada kebijakan pembelian yang bertanggung jawab di Jepang.

\subsubsection{Penggalangan hubungan sektor publik di pasar Asia}

Di saat Aliansi menjadi lebih erat hubungannya dalam menciptakan keterkaitan pasar, di lain pihak telah tumbuh pengakuan bahwa kebijakan pemerintah memainkan peran penting dalam membantu dan menciptakan permintaan untuk produk dari sumber yang lestari. Berkaitan dengan hal tersebut, Aliansi

\footnotetext{
${ }^{2}$ Lihat www.panda.org untuk melihat panduan ini.
} 
meningkatkan kerjasamanya dengan pemerintah dari negara pembeli untuk mempromosikan kebijakan penting tersebut. Kegiatan penting ini telah berlangsung di Cina, Jepang, dan pada tingkat regional.

WWF Cina membantu memfasilitasi tim pencari fakta dari Administrasi Hutan Negara Cina dan administrasi Sertifikasi dan Akreditasi ke Eropa. Rombongan tersebut mengunjungi kantor pusat dua lembaga sertifikasi internasional yaitu Forest Stewardship Council di Jerman dan PEFC (Programme for Endorsement of Forest Certification Schemes) di Luxemburg, dan juga distributor dan pengecer produk kayu serta pejabat pemerintah di UK. Hasil dari perjalanan tersebut adalah bahwa rombongan menyetujui untuk sebuah proses promosi sertifikasi hutan di Cina. Saat ini WWF sedang bekerja dengan departemen terkait dan para pihak kunci untuk merancang sebuah rencana kerja untuk pengimplementasian proses ini.

TNC dan WWF adalah dua organisasi utama dalam dialog bisnis pada pemberantasan pembalakan liar yang digelar atas dukungan dari "Dialog Kehutanan" di Hongkong pada Maret 2005. Kegiatan ini menarik minat sekitar 120 pemimpin bisnis untuk hadir, pada acara tersebut, disamping kelompok masyarakat dan pemerintah. Pada acara tersebut terjadi kesepakatan bahwa perusahaan dan pemerintah harus mengambil tanggung jawab untuk menjamin bahwa produk kayu dan kertas yang mereka beli berasal dari sumber yang legal. ${ }^{3}$ Pertemuan informal antara delegasi Indonesia dan Cina terlaksana dengan sukses pada pertemuan tersebut, yang merupakan pertama kalinya sejak dua delegasi pemerintahan tersebut menandatangani $\mathrm{MoU}$ dua tahun yang lalu, dan kemajuan yang dicapai pada saat ini adalah persetujuan pada langkah-langkah tindak lanjut.

Pada Januari 2006, direktur baru dari TNC Asia-Pasifik untuk Program Kehutanan bertemu dengan delegasi dari State Forest Authority (SFA) di Beijing dan mendiskusikan mengenai berbagai kemungkinan kerjasama antara TNC/ dan SFA. Butir persetujuan kerjasama tersebut diantaranya mencakup sebuah kunjungan SFA ke Indonesia pada pertengahan 2006 untuk meningkatkan pemahaman umum mengenai permasalahan di tahun 2006 dan untuk merancang saling pengertian tentang berbagai topik dengan pejabat Indonesia, sebagai bagian dari kerjasama untuk mendukung sebuah dialog akbar internasional mengenai pembalakan liar dan perdagangan yang akan diselenggarakan di Beijing pada pertengahan semester pertama di tahun 2007.

\footnotetext{
${ }^{3}$ www.theforestsdialog.org
} 
WWF Jepang memberikan masukan kepada Kelompok Kerja Pembalakan Liar dalam Instansi Kehutanan Jepang. WWF Jepang membantu mempromosikan berbagai pandangan dari komunitas NGO dalam perannya di Kelompok Kerja tersebut, dan dua anggota dari kelompok kerja tersebut telah menghadiri pertemuan dan diskusi kehutanan di Hong Kong. Pada skala lokal, WWF Jepang dan Mie Prefecture di Jepang Barat daya mengadakan seminar dan diskusi panel yang diselenggarakan bersamaan dengan pameran produk kayu bersertifikat dari FSC.

TNC dan WWF melanjutkan kegiatan asistensinya dalam kegiatan pembangunan Kemitraan Kehutanan dan secara terus menerus ikut membantu mengembangkan Kemitraan Kehutanan Asia (Asia Forest Partnership - AFP). Bersama dengan AFP, TNC menyelenggarakan analisis mengenai peluang dan hambatannya dari aspek legal untuk mengatasi perdagangan kayu illegal di seluruh Asia. WWF mengambil inisiatif untuk memimpin sebuah inisiasi afiliasi AFP yang melibatkan instansi yang terkait dengan AFP (Tropenbos International-Indonesia, CIFOR, dan Kementerian Kerjasama Pembangunan Pemerintah Belanda), yang bertujuan untuk mempromosikan pengelolaan hutan lestari (SFM) di Kalimantan.

Bagian penting dari berbagai upaya Aliansi tersebut adalah terbentuknya promosi mengenai kemitraan antara instansi kehutanan dan Bea Cukai, yang menjadi pusat perhatian utama dari AFP dan proses Asia-FLEG, yang akan digunakan sebagai wilayah sentral (focal area) untuk masukan pada pertemuan para menteri yang tergabung dalam FLEG pada tahun 2007 mendatang.

\subsection{Peningkatan ketersediaan produk kayu Indonesia yang bersertifikat}

\subsubsection{Peresmian jaringan kehutanan dan perdagangan (FTN) Indonesia} Hasil utama yang dicapai dari Aliansi antara WWF dan TNC adalah terbentuknya orientasi-produksi Indonesia FTN, Nusa Hijau, pada Oktober 2003. Saat ini Nusa Hijau memiliki empat peserta di bidang kehutanan, yang masing-masing mengelola: hutan alam dengan sertifikasi; hutan alam tanpa sertifikasi; hutan tanaman akasia tanpa sertifikasi; dan lima unit pengelolaan hutan jati pada skala kabupaten. Sebagai kelanjutannya, tujuh manager kehutanan pada skala industri dan enam manajer kehutanan masyarakat telah mengajukan permohonan untuk bergabung dan saat ini sedang dalam status persiapan perencanaan kegiatan. Pada 
bidang perindustrian, FTN Indonesia saat ini memiliki delapan peserta di bidang perdagangan, diikuti dengan delapan pemohon.

Untuk beberapa tahun, WWF menemukan adanya penurunan kemauan manager/ pengusaha kehutanan untuk menjadi peserta FTN Indonesia karena ketidakjelasan status legalitas di Indonesia dan lamanya waktu penyusunan kriteria yang akan digunakan dalam standarisasi legalitas MoU.

\subsubsection{Dukungan sertifikasi hutan di Indonesia}

Aktivitas Aliansi memberikan kontribusi pada pencapaian sertifikasi dari $\mathrm{HPH}$ besar di Kalimantan, dan juga sertifikasi hutan rakyat yang pertama.

\section{PT. Sumalindo Lestari Jaya II (PT.SLJ II)}

PT. SLJ II yang mengelola hutan alam seluas 270.000 ha dan terletak di Kalimantan Timur, menerima sertifikat FSC dan LEI pada awal 2006. Saat ini SLJ II menjadi tapak terbesar sertifikasi hutan berdasarkan sistem FSC di Asia Tenggara, dan merupakan manajemen hutan alam ketiga yang memperoleh sertifikat dari FSC.

Peran TNC dalam proses tersebut adalah menyediakan pelatihan dan bantuan kepada PT. SLJ II untuk identifikasi dan pengembangan aturan pengelolaan untuk HCVF, pengembangan rencana monitoring keanekaragaman hayati, mendidik para staf untuk melakukan teknik pemantauan keanekaragaman hayati, mencari kelemahan dan kekuatan sesuai dengan standar UK-RI MoU dalam hal standar legalitas, dan memperkuat sistem CoC perusahaan. Saat ini TNC masih melakukan kerjasama dengan PT. SLJ II untuk mendukung kegiatan pemantauan tambahan pada keanekaragaman hayati sesuai dengan persyaratan sertifikasi FSC.

Dalam pencapaian sertifikasi, PT. SLJ II menjadi anggota pertama dari FTN Nusa Hijau. Saat ini WWF mendukung perusahaan tersebut untuk membina hubungan perdagangan dengan pembeli yang berkeinginan untuk membeli produk yang bersertifikat.

\section{Dukungan kepada sertifikasi LEI untuk hutan rakyat yang pertama}

Pada 18 Oktober 2004, LEI memberikan sertifikat pengelolaan hutan rakyat lestari kepada dua kelompok masyarakat pengelola hutan jati di Wonogiri, Jawa Tengah, yang keduanya dibantu oleh WWF dan LSM lokal. Melalui sertifikat 
hutan rakyat ini memungkinkan LEI untuk melakukan uji lapangan dan memperbaharui standar pengelolaan hutan lestari berbasis masyarakat. Sertifikasi tersebut meliputi 800 ha area hutan Jati dan Mahoni. WWF telah menjalin kerjasama dengan LSM lokal sejak Juli 2004, termasuk ARuPA dan Persepsi untuk mempromosikan Pengelolaan Hutan Lestari dan meningkatkan akses pasar di hutan rakyat Wonogiri melalui skema LEI dalam sistem sertifikasi hutan lestari berbasis masyarakat. Perintis sertifikasi ini telah menunjukkan bahwa sertifikasi dapat membantu masyarakat untuk memperoleh keuntungan ekonomi.

WWF memulai sebuah kegiatan percontohan ke dua di Gunung Kidul. Kelompok kerja dibentuk untuk mencapai sertifikasi. LSM yang menjadi mitra WWF yaitu ARuPA, merencanakan untuk terus mendukung kelompok kerja ini dengan tujuan mencapai sertifikasi hutan rakyat di dua dusun (Blimbing dan Mendak) dalam satu tahun.

\subsubsection{Promosi pemahaman dari sertifikasi hutan dan isu pembalakan} liar

Aktivitas penyadaran publik dilakukan oleh Aliansi diantaranya melalui Media TV, panggung dialog, iklan, poster, pameran, buku panduan, surat kabar, dua film dokumenter, dan promosi dari laporan investigasi di majalah dan koran nasional. Artikel dari Aliansi dan aktivitasnya terbit di Business Week, Far Eastern Economic review, The Wall Street Journal, The Jakarta Post, Tempo, The Economist.

WWF berupaya terus untuk meningkatkan kualitas dari www.forestandtradeasia. org, sebuah website dengan multi bahasa (Inggris, Cina, Jepang, Vietnam, dan Indonesia). Website tersebut berperan sebagai pusat informasi tentang sertifikasi dan kehutanan yang bertanggung jawab di wilayah Asia Pasifik. Pada tahun 2006, site ini rata-rata dikunjungi 50.000 hit setiap bulannya.

\subsection{Peragaan solusi praktis untuk mencapai sertifikasi dan membedakan sumber kayu legal dan ilegal}

Pelaksanaan sertifikasi di Indonesia menghadapi beberapa hambatan termasuk lemahnya dukungan dari LSM, Pemerintah, dan kesulitan dalam melacak kayu dari sumber penghasil ke pasar, serta kurangnya kesepakatan tentang definisi dari legalitas Aliansi telah memulai untuk menanggapi permasalahan ini dengan serius dan pada tahun kedua dan ketiga dari program tersebut telah membuat kontribusi yang berarti pada pendefinisian legalitas serta pengembangan teknologi yang 
handal untuk lacak balak. Selama kegiatan ini berlangsung, Aliansi telah membuat beberapa perubahan penting dalam pendekatan yang dilakukan sehubungan dengan meningkatnya kesadaran terhadap isu-isu dan perkembangan politik untuk mencapai hal tersebut. Pada definisi legalitas, saat ini secara jelas diperlukan keterlibatan penuh dari para pihak untuk meningkatkan rasa memiliki mereka akan standar tersebut dan secara konstruktif tergabung dalam proses-proses yang ada di dalamnya. Setelah mengembangkan sebuah draft standar legalitas, TNC menyerahkan proses ini untuk diolah kembali dalam sebuah steering komite yang terdiri dari perwakilan dari para pihak termasuk: Departemen Kehutanan, Pengusaha Hutan, Asosiasi Industri perkayuan, serta LSM sosial dan lingkungan. Pada kegiatan lacak balak ini, dengan adanya peningkatan kemauan politik dari pemerintah, memungkinkan TNC untuk mempromosikan pengadopsian sebuah sistem lacak balak nasional, hal tersebut manfaatnya jauh lebih berharga dari pada strategi berbasis pasar yang sebelumnya telah diadopsi.

Solusi praktis lain untuk pencapaian sertifikasi yang disusun oleh Aliansi pada periode ini termasuk alat untuk identifikasi dan deliniasi High Conservation Value Forest $(\mathrm{HCVF})$ dan penyusunan model pengelolaan bersama untuk menjamin pengelolaan yang saling menguntungkan antara masyarakat lokal dengan HPH dari sumberdaya hutan yang ada.

\subsubsection{Definisi “Legal”}

Salah satu langkah pertama dalam pendekatan bertahap dari Aliansi adalah kepemilikan "legalitas pemanenan" dari Pengusaha Hutan. Kondisi penegakan hukum yang tidak menentu, prosedur administrasi yang tidak jelas, dan ketidakjelasan status ketentuan hukum yang terjadi di Indonesia, telah mengakibatkan terjadinya kesulitan dalam pelaksanaan verifikasi, apakah sebuah perusahaan beroperasi secara legal. Hal ini mengakibatkan verifikasi legalitas memiliki kemungkinan tingkat kesulitan yang hampir sama dengan proses pencapaian sertifikasi hutan lestari. Sebuah standar legalitas dapat membantu menyelesaikan permasalahan-permasalahan tersebut dengan mengusulkan kriteria yang jelas serta dapat diaudit dan diverifikasi oleh auditor independen ketika pelaksanaan audit legalitas atau komponen persyaratan legal dari standar sukarela (voluntary standard) sertifikasi seperti pada prinsip pertama FSC.

Sebuah draft definisi dari legalitas dikembangkan dalam rangkaian proses MoU antara UK dan Indonesia melalui sebuah proses partisipasi para pihak yang melibatkan Kabupaten, Propinsi, dan para pihak di pusat (Jakarta). 
Setelah draft tersebut selesai dikembangkan, TNC memutuskan bahwa proses pemantapan standar legalitas akan lebih baik dikelola oleh organisasi lokal dan Lembaga Ekolabel Indonesia (LEI) telah dinominasikan sebagai lembaga yang akan melanjutkan pengembangan standar tersebut di masa mendatang. TNC menyerahkan pengurusan standar ini kepada LEI pada akhir 2005, dan sejak saat itu LEI telah membentuk sebuah kelompok kerja teknis dimana TNC juga merupakan bagian darinya, yang bertujuan untuk menyelesaikan standar tersebut. Sebuah dewan pengarah yang dipimpin oleh Sekretaris Jenderal Dephut yang bertugas untuk mengawasi perkembangan dari standar ini telah terbentuk pada semester pertama tahun 2006.

WWF menyelesaikan sebuah draft lanjutan dari “Keep it Legal"- sebuah panduan untuk para pebisnis kayu agar menjamin legalitasnya dalam rantai pasokan bahan baku. Panduan tersebut menjelaskan kondisi dan besarnya permasalahan pembalakan liar serta ancamannya terhadap hutan serta sumber kehidupan masyarakat yang tergantung dari hutan. Panduan tersebut menjelaskan sebuah pendekatan sistematis untuk mengidentifikasi dan menghilangkan resiko dari masuknya kayu ilegal dalam rantai sumber bahan baku, dan menjelaskan beberapa tantangan yang menyertainya dalam mengembangkan transparansi, keadilan dan kebijakan yang realistis pada pemenuhan aspek legal. WWF saat ini sedang mengembangkan sebuah Panduan Negara untuk melengkapi panduan generik “Keep it legal”. Panduan Negara ini juga akan memuat sebuah penjelasan pada standar legalitas dan petunjuk penggunaannya untuk mendukung proses pembelian yang bertanggung jawab.

\subsubsection{Pengembangan verifikasi legalitas independen dan sistem lacak balak}

SGS/URS sebagai konsultan TNC telah menyelesaikan sebuah sistem lacak balak sebagai kelengkapan dari standar legalitas. Sistem ini sukses diujicobakan di PT.SLJ II. Uji coba ini dimulai dengan sebuah audit dari tujuh prinsip legalitas yang dibuat oleh $\mathrm{MoU}$ standar legalitas dan diikuti oleh pelacakan kayu dari hutan (tunggak) ke industri.

Sejak permulaan dari uji coba dari sistem lacak balak, Dephut juga telah menyelesaikan pengembangan sistem lacak-balaknya. Diskusi yang diprakarsai oleh TNC telah menghasilkan sebuah surat persetujuan antara MoF, TNC dan TFT untuk melakukan uji lapangan gabungan "Sistem Administrasi Kayu” yang terdiri dari sistem Dephut dan sistem TNC, serta untuk mengujicobakan sebuah 
sistem pelacakan komersial terpisah yang disebut TracElite. Pada saat sistem tersebut sudah diujicobakan, Dephut merencanakan untuk menyebarluaskan sistem lacak balak ini kepada HPH secara nasional. Dephut mengharapkan sistem ini akan beroperasi penuh di seluruh daerah pada akhir 2007.

\subsubsection{Dukungan perlindungan pada Hutan dengan Nilai Konservasi Tinggi (HCVF)}

Di propinsi Riau, WWF bekerja dengan jaringan LSM lokal, Jikalahari, untuk membantu kelompok lokal dalam menyediakan informasi tentang penilaian aspek sosial dan lingkungan dari PT. APRIL (salah satu dari dua perusahaan pulp dan kertas terbesar di Riau) untuk analisis tentang HCVF di Semenanjung Kampar dan taman nasional Tesso Nilo. WWF juga sedang mengembangkan dialog dengan beberapa perusahaan kelapa sawit di Riau mengenai pengembangan koridor satwa liar dan pemeliharaan dari HCVF di dalam dan di sekitar konsesi mereka. WWF bekerjasama dengan Komisi Minyak Sawit Indonesia (IPOC), telah melakukan kegiatan secara intensif dengan perusahaan kelapa sawit untuk mencegah konversi hutan di daerah koridor HCVF.

Di Papua, WWF terus melakukan identifikasi HCVF di daerah hulu di BianKumbe-Maro. WWF juga mendukung para pihak lokal untuk membentuk sebuah forum yang bertujuan untuk mendorong proses komunikasi diantara para pihak pada isu-isu terkait dengan penggunaan lahan dan rencana tata ruang.

Di Kalimantan, TNC terus melakukan usaha untuk melindungi HCVF di daerah Kabupaten Berau dan Kutai Timur, dan menindaklanjuti negosiasi dengan pemerintah lokal, 90 persen dari HCVF di dalam Kabupaten Berau telah dimasukkan dalam rencana tata ruang kabupaten. Rencana Ekoregional dari TNC untuk Kalimantan Timur yang mengidentifikasi area HCVF pada tingkat makro telah diintegrasikan ke dalam rencana propinsi Kalimantan Timur, dan digunakan oleh Badan Planologi Dephut sebagai bahan rujukan verifikasi.

TNC juga bekerjasama dengan masyarakat adat/tempatan yang terkait dengan keberadaan hutan dan pemerintah daerah Kutai Timur untuk mengembangkan pendekatan pengelolaan kolaborasi untuk memelihara HCVF pada areal bekas $\mathrm{HPH}$ yang memiliki populasi orang hutan yang tinggi. TNC berhasil melakukan loby dengan Dephut, dan pemerintah daerah untuk mengeluarkan bekas HPH dari 
kawasan hutan produksi. Areal tersebut sekarang merupakan areal perlindungan lokal dibawah pengelolaan kolaborasi untuk mencegah pembalakan liar dan perburuan liar.

\section{Pencapaian penerimaan kriteria untuk produksi kelapa sawit secara lestari}

Pada tahun 2003, WWF bekerjasama dengan mitra bisnis memulai pertemuan minyak sawit lestari (RSPO). RSPO adalah sebuah organisasi independen nir laba yang berkonsentrasi pada promosi pengelolaan kelapa sawit secara lestari dan memperoleh sebuah definisi bersama mengenai produksi minyak sawit secara bertanggung jawab. Para anggotanya termasuk di dalamnya adalah produser, pembeli, pengecer, institusi keuangan, dan LSM. WWF berpartisipasi secara aktif dalam pengembangan sebuah kumpulan kriteria yang dikenal sebagai "Prinsip dan Kriteria untuk Produksi Minyak Sawit Lestari". Kriteria tersebut secara keseluruhan telah diterima oleh RSPO pada tahun 2005 dan memberikan panduan yang sangat penting kepada perusahaan panduan tentang hal-hal yang diperlukan untuk memproduksi minyak sawit secara ramah lingkungan dan bertanggung jawab secara sosial. Kriteria tersebut mengakui pentingnya dari HCVF, khususnya pada kriteria 7.3 yang menyatakan bahwa "Hutan primer dan setiap areal yang memiliki satu atau lebih HCVF tidak boleh dikonversi menjadi tanaman sawit”.

\subsubsection{Dukungan terhadap manajemen kolaborasi di SLJ IV}

TNC bekerja dengan lima desa di sekitar areal konsesi SLJ IV di Kalimantan Timur untuk mendukung manajemen kolaborasi. Pada Oktober 2003, TNC membentuk sebuah Badan Pengelola, yang terdiri dari perwakilan dari kelima desa tersebut, pemerintah daerah kabupaten Berau, SLJ IV, kepala adat dayak berau, dan TNC. Badan Pengelola tersebut memperoleh pelatihan dari TNC mengenai teknik perpetaan, komunikasi, penulisan proposal, pertanian terintegrasi, dan manajemen hutan rakyat. Pada 1 Juni 2004, sebuah MoU telah ditandatangani untuk mengembangkan model kolaborasi manajemen hutan rakyat antara PT SLJ IV, TNC dan masyarakat dari kelima desa tersebut. Persetujuan tersebut akan meningkatkan perencanaan partisipasi masyarakat, implementasi, dan monitoring manajemen hutan sehingga perusahaan dan masyarakat dapat memperoleh manfaat dari hutan. 


\subsection{Pengurangan dukungan finansial dan investasi pada perusahaan yang terlibat dalam perusakan hutan dan pembalakan liar}

\subsubsection{Kerja sama dengan bank untuk memperbaiki asesmen resiko lingkungan dan sosial}

Pada April 2005, WWF menyelenggarakan pertemuan di Jakarta dengan berbagai Bank dan para pihak untuk mengenali keinginan mereka dalam mengembangkan sebuah pendekatan kerja pada asesmen resiko bank di bidang perkayuan dan perkebunan di Indonesia. WWF dan bank-bank setuju untuk saling melakukan pertukaran informasi untuk mengidentifikasi target dari bank dan strategi keterlibatannya di dalam inisiatif tersebut. Saat ini WWF sedang bekerja dengan beberapa Bank dalam mengembangkan sebuah buku panduan untuk membantu pejabat resiko kredit dari bank untuk menyeleksi resiko lingkungan dan sosial proyek kelapa sawit di Indonesia.

WWF juga menyelenggarakan pertemuan dengan Bank Indonesia, Kementerian Lingkungan Hidup dan LSM konservasi dan lingkungan yang terkait, dengan tujuan mendorong Bank Indonesia untuk memperkuat persyaratan-persyaratan bagi bank-bank yang ada di Indonesia untuk melakukan seleksi investasi yang memiliki resiko dan dampak lingkungan. Pada inisiatif terkait, WWF mendukung upaya-upaya Kementerian Lingkungan Hidup dan KFW (sebuah Agen bantuan Jerman) untuk membangun kapasitas dari usaha kecil menengah untuk secara efektif memperhatikan permasalahan lingkungan dan sosial dalam proposal pinjaman, dan untuk menciptakan insentif pinjaman lunak bagi mereka untuk melakukannya. Pada Januari 2005, Bank Indonesia mengeluarkan sebuah peraturan baru yang mengharuskan bank-bank di Indonesia menilai kualitas dari pinjaman mereka. Peraturan tersebut menetapkan "Langkah-langkah yang perlu diambil oleh peminjam untuk ramah lingkungan" sebagai salah satu faktor yang perlu diperhatikan oleh para Bank. Peraturan tersebut merupakan sebuah langkah penting dalam mendorong institusi keuangan Indonesia untuk berperan dalam kelestarian dan tanggung jawab sosial.

\subsubsection{Pengaruh pada Kreditor Asia Pulp dan Paper}

Pada Agustus 2003, WWF, APP (Asia Pulp and Paper Company Ltd) dan Sinar Mas Group (SMG) menandatangani Letter of Intent (LoI) yang diantaranya 
berisi persetujuan antara APP dan SMG bahwa asesmen HCVF perlu dilakukan sebelum hutan alam dikonversi menjadi tanaman Akasia:

- Identifikasi dan konservasi HCVF;

- Tunduk dengan hukum nasional; dan

- Menyelesaikan persengketaan lahan dengan masyarakat.

Pada Februari 2004, APP menyelesaikan sebuah Rencana Aksi Kelestarian (SAP), yang menurut WWF tidak seperti harapan pada beberapa butir persetujuan dalam LoI. Sebagai akibat dari ketidaksesuaian tersebut, WWF tidak melanjutkan kerjasama tersebut dan mengakhirinya pada 19 Februari 2004. Namun demikian WWF tetap menjalin komunikasi dengan para pelanggan dan kreditor untuk tetap memberikan tekanan kepada APP untuk melakukan proses produksi sesuai dengan rencana aksi kelestariannya (SAP).

Pada Juni 2004, WWF Indonesia mempublikasikan dua buah laporan mengenai keterlibatan APP dalam pembalakan liar. Laporan tersebut dirancang untuk menginformasikan kepada pelanggan APP dan melakukan tekanan pada APP dengan membuat perubahan fundamental kebijakan pembelian mereka. Kreditor utama dari APP melakukan negosiasi sebuah persetujuan penting dalam perjanjian lingkungan yang akan menjadi bagian integral dari Persetujuan Induk Restrukturisasi antara APP dan para kreditornya. Para kreditor lebih lanjut juga mengakui adanya kebutuhan untuk sebuah putaran dari asesmen lingkungan dari areal pasokan serat kayu kepada APP. Sebagai hasilnya, APP menggandeng SmartWood, sebuah lembaga sertifikasi non profit dan independen, untuk mengidentifikasi HCVF di dalam area sumber pasok bahan baku pulp dan merekomendasikan sistem manajemen konservasi yang sesuai. 


\section{Pembelajaran Keterkaitan Kebutuhan akan Produk Kayu yang Lestari dengan Penyediaannya dari Indonesia}

\subsection{Kebutuhan produk kayu yang lestari di pasar tempat Aliansi bekerja}

Inisiatif perdagangan yang terkait dengan kepedulian lingkungan mendapat dukungan baru dengan adanya ketertarikan global terhadap isu-isu pemerintahan. Pada dekade sebelumnya, institusi pembangunan internasional telah meningkatkan pemahamannya tentang pentingnya pemerintahan yang baik pada negara tujuan, dan kepentingan ini tercermin pada berbagai pihak yang memiliki hubungan langsung dengan perdagangan kayu tropis. Isu-isu kehutanan yang relevan, termasuk di dalamnya adalah pembalakan liar dan perdagangan produk kayu yang berasal dari pembalakan liar, secara umum menjadi bahan diskusi dalam FLEG pada tingkat pemerintahan pusat dan daerah serta peserta dari industri kehutanan. Pihak-pihak tersebut memiliki peran dalam mempromosikan mekanisme untuk menghambat perdagangan produk kayu dari pembalakan liar dan beberapa mekanisme lainnya, termasuk program legalisasi oleh pembeli umum dan swasta serta peraturan perdagangan.

Bagian selanjutnya adalah mengenai permintaan produk kayu yang lestari dari Indonesia di pasar yang secara aktif telah dibangun oleh Aliansi. Pasar tersebut diantaranya adalah Uni Eropa, Amerika Serikat, Jepang dan Cina. Pasar Eropa dan Amerika Utara dikenal sebagai pasar yang 'Sensitif terhadap lingkungan' tetapi tetap menjadi importir penting untuk produk perkayuan Indonesia, yang sebagian besar berasal dari sumber yang tidak lestari. Kebijakan yang saat ini berjalan dalam pasar sepertinya ditujukan untuk mengurangi perdagangan tersebut dalam jumlah yang signifikan pada masa yang akan datang. Pasar Jepang dan Cina selama ini dikenal kurang peduli dengan kelestarian kayu yang mereka import, tetapi dengan adanya kegiatan dalam Aliansi, faktor kelestarian ini perlahan-lahan akan dimasukan ke dalam pasar tersebut. 


\subsubsection{Uni Eropa}

Uni Eropa selama ini dikenal sebagai pasar yang memiliki kepedulian lingkungan yang tinggi. Pada negara-negara konsumen utama di Eropa, seperti Inggris, Jerman dan Belanda, organisasi lingkungan besar seperti WWF dan Greenpeace memiliki pengaruh yang besar terhadap tradisi perusahaan. Pada umumnya, isu lingkungan akan menjadi bahan perbincangan politik yang utama pada tingkat pemerintahan pusat maupun daerah, baik pada negara-negara anggota maupun pada tingkat regional Uni Eropa. Keterlibatan pusat dan daerah ini didukung oleh berbagai pihak di Uni Eropa di bawah EC Rencana Kegiatan dalam Penegakan Kebijakan Kehutanan dan Perdagangan (Forest Law Enforcement and Trade - FLEGT).

Para pembeli potensial untuk produk perkayuan dari Indonesia di Uni Eropa dilibatkan dalam proses pengurangan atau penghilangan penggunaan produk kayu yang berasal dari pembalakan liar ataupun dari sumber yang tidak lestari. Sebagai upaya untuk merespon tekanan dari LSM lingkungan, pembeli melakukan perhitungan ulang tentang ketersediaan kayu yang ada dan melaksanakan kebijakan yang telah ada, untuk mengurangi terjadinya penurunan citra perusahaan.

Pada beberapa perusahaan hal ini mengakibatkan terjadinya pemberhentian kegiatan perdagangan kayu yang berasal dari negara yang memiliki resiko tinggi, seperti Indonesia. Sebagai contoh, berdasarkan kampanye yang dilakukan oleh Greenpeace pada tahun 2004, empat pembeli besar produk perkayuan Indonesia di Inggris menghentikan pembeliannya. ${ }^{4} \mathrm{~B} \& \mathrm{Q}$, pedagang besar Inggris DIY, saat ini melakukan pembelian produk plywood dari sumber yang memiliki sertifikasi dari FSC di Brazil ${ }^{5}$ dan Travis Perkins, pedagang besar Inggris untuk kayu tropis, mengalihkan pembelian kayu dari Indonesia ke kayu legal dari Ghana. Perusahaan-perusahaan lain di Uni Eropa bekerjasama dengan LSM besar seperti WWF untuk mendapatkan sumber kayu yang legal ataupun yang berasal dari sumber yang lestari di Indonesia.

WWF dengan dukungan dari 'Kelompok pembeli' atau Jaringan Kehutanan dan Perdagangan (Forest and Trade Networks - FTNs), di Uni Eropa dan termasuk took DIY, supermarket, toko perlengkapan rumah tangga, perusahaan produk perkayuan, importer kayu dan perdagangan, pemborong, dan konstruksi pembangunan sangat peduli untuk tetap membeli dan menjual produk perkayuan yang berasal dari sumber yang lestari. Beberapa anggota WWF FTNs Eropa telah

\footnotetext{
${ }^{4}$ RIIA 2004.

${ }^{5}$ Steve Crewe, personal communication.
} 
menghentikan pembelian produk kayu dari Indonesia, ${ }^{6}$ sementara yang lainnya aktif mencari keberadaan kayu legal dari Indonesia dengan dukungan dari FTN Indonesia. Pada Juni 2006, WWF FTNs Eropa telah memiliki anggota kurang lebih 180.

Sebagai bagian dari kegiatan aliansi, TNC telah mengunjungi beberapa organisasi swasta yang terkait dengan perdagangan kayu tropis, termasuk didalamnya adalah importer kayu dari Indonesia di Inggris dan Belanda dan federasi perdagangan kayu di Inggris, Perancis dan Belgia. Federasi tersebut bersama dengan Belanda, terlibat dalam proyek lima tahun untuk kegiatan identifikasi kayu legal dari Indonesia, Malaysia, Cameroon dan Gabon dan penelusuran pasar pada negara masing-masing. Perusahaan yang dikunjungi diantaranya adalah Finnforest Inggris (yang telah menangguhkan pembelian dari Indonesia, menunggu kepastian sistem untuk verifikasi legalitas) dan FETIM, Dekker Hout dan Jongeneel di Belanda. Aliansi juga memelihara kontak dengan Kingfisher di Inggris sebagai pemasok untuk jaringan B\&Q DIY.

Beberapa pemerintah di tingkat nasional, regional dan propinsi di Uni Eropa berada pada berbagai status penyusunan kebijakan yang mungkin akan memberikan pengaruh terhadap pembelian produk perkayuan dari Indonesia. Sektor publik merupakan pangsa pasar terbesar di Uni Eropa dan hanya sekitar 20\% kebutuhan kayu di Eropa berasal dari institusi pemerintah. Kebijakan pembelian pada skala nasional sebagai usaha untuk memastikan bahwa kayu yang digunakan adalah kayu yang legal dan berasal dari sumber yang lestari sedang disusun di Inggris, Belanda, Perancis, Jerman dan Denmark. ${ }^{7}$ Sebagai contoh pada Agustus 2005, Jerman mempresentasikan rancangan perundangan yang mengharuskan perusahaan perkayuan di Jerman untuk melakukan impor kayu dari sumber yang legal. Undang-undang tersebut tidak memperkenankan adanya impor ataupun pemasaran kayu dengan sumber yang tidak legal pada negaranegara di luar Uni Eropa.

Pada Oktober 2002, pemerintah Inggris meluncurkan program FLEG - yang juga dikenal dengan program pembalakan liar (Illegal Logging Program). Hal ini ditujukan untuk memfasilitasi institusi nasional, regional dan internasional dalam memecahkan permasalahan pembalakan liar dan perdagangan kayu dari sumber yang tidak legal pada skala internasional. Program ini bertujuan untuk memberikan

${ }^{6}$ Steve Crewe, personal communication.

${ }^{7}$ RIIA 2004. 
pemahaman yang lebih baik mengenai penyebab terjadinya pembalakan liar dan membangun kerjasama antar pihak dalam skala yang lebih luas dalam penyusunan dan implementasi pemecahan masalah. Sebagai bagian dari program FLEG, pemerintah Inggris dan pemerintah Indonesia menandatangani kesepakatan kerjasama dalam hal pembalakan liar yang merupakan hasil komitmen dari pemerintah Inggris dan pemerintah Indonesia untuk:

Bekerjasama untuk mengurangi, dan pada akhirnya menghapuskan, terjadinya pembalakan liar dan perdagangan internasional untuk kayu serta produk kayu yang berasal dari sumber yang tidak legal antara [Indonesia dan Inggris], melalui penyusunan dan implementasi peraturan yang diperlukan dan perubahan kebijakan jangka pendek.

FLEG program Inggris telah bekerjasama dengan TNC dan pemerintah Indonesia untuk menyusun definisi mengenai kayu legal di Indonesia (lihat bagian 4).

\section{Rencana Kegiatan Uni Eropa untuk Penegakan Hukum Kebutanan, Pemerintaban dan Perdagangan (FLEGT).}

Pada Mei 2003, Komisi Eropa meluncurkan rencana kegiatan Uni Eropa untuk Penegakan Hukum Kehutanan, Pemerintahan dan Perdagangan (Forest Law Enforcement, Governance and Trade-FLEGT). Hal ini menjadi tanda dimulainya suatu proses yang panjang dalam penyusunan dan implementasi tindakantindakan yang akan dilakukan untuk menjawab permasalahan pembalakan liar dan perdagangan yang terkait dengan pembalakan liar. Tindakan-tindakan yang disusun dalam rencana kegiatan FLEGT ini diantaranya adalah:

- Dukungan terhadap kemampuan pemerintah dan peningkatan kemampuan di negara-negara penghasil kayu.

- Penyusunan Kesepakatan Kemitraan dengan negara-negara penghasil kayu untuk mencegah adanya produk kayu ilegal masuk ke Uni Eropa.

- Usaha-usaha untuk mengurangi konsumsi kayu di Uni Eropa yang berasal dari kayu ilegal dan menutup investasi yang dilakukan oleh institusi Uni Eropa yang mungkin mendorong terjadinya pembalakan liar. ${ }^{8}$

Hal yang paling penting dari tindakan-tindakan tersebut adalah terwujudnya lisensi sistem untuk pembalakan liar berdasarkan Kesepakatan Kemitraan Sukarela (Voluntary Partnership Agreements - VPAs) dengan negara-negara penghasil kayu. Skema ini diharapkan dapat mencakup produk kayu gergajian, kayu bulat, kayu lapis dan veneer, serta pada waktu yang akan datang dapat mencakup produk

${ }^{8}$ FLEGT Briefing Notes, http://europa.eu.int 
perkayuan yang lain. Skema ini diharapkan dapat diimplementasikan dengan dasar suka rela (berdasarkan persetujuan) oleh negara pemasok kayu yang masuk dalam anggota VPA melalui Uni Eropa.

Pada proses penyusunan skema lisensi, kajian mengenai kebijakan nasional yang berlaku serta pilihan kebijakan dan peraturan pada skala nasional dan di tingkat Uni Eropa menjadi perhatian utama dalam FLEGT. Pilihan-pilihan tersebut mencakup peraturan di bidang anti pencucian uang (anti-money laundering), peraturan kejahatan seperti hukum yang mengatur mengenai aliran barangbarang curian, dan kemungkinan untuk mencegah impor produk kayu illegal ke Uni Eropa. ${ }^{9}$

\subsubsection{Amerika Serikat}

Amerika Serikat memiliki berbagai sektor publik dan swasta yang terkait dengan kepedulian terhadap deforestasi yang mungkin akan berpengaruh terhadap import produk perkayuan dari Indonesia. Pada sisi swasta, beberapa importir besar produk perkayuan Indonesia merespon tekanan dari LSM lingkungan dan melakukan evaluasi ulang terhadap rantai persediaan kayu mereka. Sebagai contoh, International Paper, pemimpin dalam produk kehutanan global, menandatangani kesepakatan penangguhan pembelian kayu dari Indonesia "sampai pemerintah Indonesia dan HPH-HPH yang ada melakukan langkah yang diperlukan untuk melindungi hutan dan kembali pada praktek kehutanan yang lestari." Home Depot, pedagang terbesar dunia untuk produk rumah tangga, saat ini mengurangi pembelian kayu lapis (plywood) dari Indonesia hingga $70 \%$ dari jumlah pembelian pada tahun 1999. Centex Homes, pemborong besar di Amerika serikat telah menghentikan penggunaan kayu dari Indonesia. ${ }^{10}$

Beberapa pihak di pemerintahan dan kota melakukan larangan penggunaan produk kayu tropis pada proyek-proyek publik. Beberapa kota di Amerika serikat bahkan telah mengeluarkan larangan pembelian kayu tropis. ${ }^{11}$

Bagian kepresidenan Amerika Serikat untuk perlawanan terhadap pembalakan liar bertujuan untuk membantu negara berkembang dalam melawan pembalakan liar dan perdagangan kayu yang terkait di dalamnya serta untuk mengurangi korupsi

\footnotetext{
9 FLEGT Briefing Notes, http://europa.eu.int

${ }^{10}$ http://www.ran.org/ran_campaigns/old_growth/indonesia/

11 ITTO 1999.
} 
di sektor kehutanan. Badan ini memfasilitasi kemitraan di bawah USAIDs Aliansi Global untuk Produk Kehutanan yang Lestari (Sustainable Forest Products Global Alliance) untuk mewujudkan produk kehutanan dari sumber yang legal. Salah satu kemitraan tersebut adalah aliansi antara WWF/TNC untuk mempromosikan sertifikasi dan melawan pembalakan liar di Indonesia. Kegiatan lebih lanjut mengenai program ini di Indonesia akan mencakup:

- Pengelolaan dan perlindungan hutan berbasis masyarakat.

- Mempromosikan tata pemerintahan (governance), transparansi dan akuntabilitas di bidang kehutanan.

- Memusatkan perhatian pada pembalakan liar yang mengganggu habitat orangutan.

- Menindaklanjuti hasil dari Konferensi tingkat menteri Asia Timur untuk Penegakan Hukum Kehutanan dan Pemerintahan (East Asia Ministerial Conference on Forest Law Enforcement and Governance). ${ }^{12}$

\subsubsection{Jepang}

Kepedulian lingkungan di Jepang dikenal lebih rendah dibandingkan dengan Eropa barat dan Amerika serikat, tetapi beberapa proses mengindikasikan bahwa pasar Jepang menjadi lebih peka terhadap isu-isu kelestarian. Berdasarkan ITTO, terdapat suatu "Pergerakan Hijau" (Green Movement) dari LSM lokal tentang penipisan sumberdaya hutan tropis yang diliput oleh media. ${ }^{13} \mathrm{Hal}$ terpenting terjadi setelah perusahaan terkemuka di Jepang menerima sertifikasi dari FSC Forest Management (FM) pada tahun 2002, yang mengakibatkan terjadinya perubahan besar di Jepang. Pada awal tahun 2006, terdapat 24 perusahaan dengan sertifikasi dari FSC FM dan jumlah jaringan Sertifikasi FSC Chain of Custody $(\mathrm{CoC})$ mencapai angka 288, yang merupakan lima tertinggi di dunia. ${ }^{14}$

Beberapa perusahaan besar di Jepang termasuk Canon Group, Nippon Paper Group, Fuji Xerox, Ricoh, ASKUL, Oji Paper dan Mitsubishi Paper Mill telah menerapkan kebijakan bertanggung jawab dalam pembelian kertas. WWF membantu Ricoh, ASKUl (pemasok utama untuk alat tulis dan perkantoran di Jepang) dalam merencanakan kebijakan bertanggung jawab dalam pembelian kertas mereka. Ricoh telah menghentikan pembelian dari pemasok Indonesia karena tidak memenuhi standar yang mereka terapkan, dan ASKUL sebagai pembeli terbesar dari APP telah mengalihkan ke perkebunan serat. Mitsubishi Paper Mill dan Fuji Xerox adalah anggota dari WWF FTN Jepang.

\footnotetext{
${ }^{12}$ http://www.whitehouse.gov/infocus/illegal-logging/piail.html

${ }^{13}$ ITTO 1999.

${ }^{14}$ http://www.certified-forests.org/data/coc3.htm
} 
Pada tahun 2003, pemerintah Jepang dan Indonesia melakukan Peluncuran Bersama untuk Kerjasama dalam Memerangi Pembalakan Liar dan Perdagangan Kayu Ilegal dan Produk Perkayuan (Joint Announcement on the Cooperation in Combating Illegal Logging and the Trade in Illegally Logged Timber and Wood Products). Secara terinci rencana kegiatan yang dilakukan adalah untuk menyusun, uji coba dan implementasi sistem untuk verifikasi kebutuhan legal, dan kolaborasi efektif antara institusi terkait dan jaringan yang akan mempengaruhi legalitas produk yang dihasilkan dan diperdagangkan. Meskipun demikian, implementasi dari kegiatan yang terkait dengan kesepakatan dilaporkan bergerak dengan lambat. ${ }^{15}$

Jepang sedang mempersiapkan kebijakan pengadaan produk perkayuan untuk keperluan domestik dan impor berdasarkan hasil amandemen dari Rencana Dasar Kepedulian Hukum untuk Promosi Pengadaan Barang dan jasa yang Ramah Lingkungan (Basic Plan of the Law Concerning the Promotion of Procurement of Eco-Friendly Goods and Services) oleh negara dan pihak terkait (Hukum dalam Promosi Pembelian Hijau - Law on Promoting Green Purchasing). Sebagai bagian dari proses ini, Institusi Kehutanan Jepang telah menerbitkan "Panduan untuk Verifikasi Legalitas dan Kelestarian Kayu dan Produk Perkayuan" (Guideline for Verification on Legality and Sustainability of Wood and Wood Products). ${ }^{16} 16$ Rencana dasar ini bertujuan bahwa kayu yang berasal dari hutan alam harus "melalui pemanenan yang legal atau diproduksi dari pengelolaan hutan yang lestari" dan diaplikasikan dalam penggunaan kayu untuk kertas, perkakas kantor dan rumah tangga, dan material konstruksi. Melalui panduan ini, bukti legalitas dan kelestarian dapat diberikan oleh salah satu dari tiga institusi yang ada, yaitu:

- Petugas di bidang sertifikasi pengelolaan hutan.

- Institusi yang diakreditasi oleh asosiasi kehutanan atau perusahaan perkayuan; atau

- Perusahaan itu sendiri (deklarasi sendiri). ${ }^{17}$

\subsubsection{Cina}

Impor kayu ke Cina meningkat cukup tajam dan hal ini terus berlanjut seiring dengan berlebihnya permintaan untuk kebutuhan domestik dan ekspor dibandingkan dengan produksi kayu domestik. Eksploitasi hutan alam yang berlebihan pada beberapa wilayah telah menghabiskan volume tegakan, sedangkan

\footnotetext{
1515 RIIA 2004.

${ }^{16}$ http://www.rinya.maff.go.jp/policy2/ihou/eiyaku.pdf

${ }^{17}$ http://www.forestandtradeasia.org/posting/japan/english/498/
} 
pada sisi lain penerapan larangan tebang dan penetapan batas produksi dilakukan pada beberapa area yang masih memiliki potensi yang cukup tinggi. Konsumsi domestik meningkat cukup tajam seiring dengan pertumbuhan ekonomi dan peningkatan standar hidup di Cina, ${ }^{18}$ begitu pula dengan ekspor produk perkayuan dengan nilai tambah yang mengalami peningkatan secara signifikan.

Pasar Cina memiliki peran penting dalam pasar yang berpotensi meningkatkan kondisi pengelolaan hutan di Indonesia. Meskipun demikian, pembeli-pembeli dari Cina sangat lambat dalam melakukan implementasi kewajiban dalam program pembelian, dan ditengarai bahwa Cina adalah tujuan terbesar perdagangan kayu ilegal dari Indonesia. Seiring dengan semakin selektifnya pasar Eropa dan Amerika Utara, akan sangat berbahaya apabila produsen kayu di Indonesia mengalihkan penjualannya ke Cina sebagai upaya untuk menghindari kriteria pasar akan kepedulian lingkungan. Pada akhirnya beberapa faktor diharapkan dapat meningkatkan kepedulian pasar Cina untuk lebih sensitif terhadap lingkungan di masa mendatang.

Jaringan pasar ke Eropa dan Amerika Serikat secara terus-menerus mendorong perkembangan sertifikasi hutan di Cina. Institusi pemerintah, akademisi dan praktisi kehutanan di Cina berupaya untuk menyusun standar sertifikasi nasional dan sistem yang akan memenuhi kebutuhan pasar internasional. Proses ini secara aktif didukung oleh beberapa organisasi internasional seperti World bank/Aliansi WWF yang telah bekerja untuk meningkatkan kemampuan sertifikasi hutan di Cina melalui beberapa pelatihan dan seminar.

Pada Juni 2006, empat unit pengelolaan hutan memperoleh sertifikasi pengelolaan hutan dari FSC dan 150 perusahaan mendapatkan sertifikasi CoC FSC. WWF FTN Cina yang dibentuk pada Maret 2005 berhasil mendapatkan lima perusahaan dari Cina dan tiga perusahaan Hong Kong sebagai anggota pertamanya. Termasuk dalam perusahaan tersebut adalah dua pemegang konsesi pengusahaan hutan terbesar di Cina, tiga perusahaan besar di bidang perkayuan di Cina daratan dan tiga perusahaan perdagangan di Hong Kong.

Sertifikasi di Cina selama ini dipicu oleh adanya kebutuhan akan kayu yang lestari untuk pasar ekspor. Pada tahun 2002, seluruh perusahaan di Cina yang mendapatkan sertifikasi CoC dari FSC adalah pengekspor produk furnitur kayu. ${ }^{19}$

\footnotetext{
${ }^{18}$ Chunquan Zhu, et al. 2004.

${ }^{19}$ Wenming et al. 2002.
} 
Pada saat yang bersamaan, seluruh anggota FTN Cina yang memiliki hubungan dengan Indonesia telah melebarkan pemasarannya ke Eropa dan Amerika Utara. Sebagai contoh Kingsfier yang merupakan pedagang yang membeli produk kayu untuk B\&Q Iyingbin Inggris, yang bekerja sama dengan WWF untuk melakukan identifikasi sumber kayu yang legal di Indonesia juga memiliki hubungan pasar dengan Amerika Utara dan Eropa.

Pada Desember 2002, Cina dan Indonesia melakukan penandatanganan kesepakatan dalam bidang pembalakan liar. Kesepakatan tersebut mencakup aturan dan kewajiban yang harus dipenuhi oleh masing-masing pihak untuk melawan pembalakan liar dan perdagangan produk kayu dari pembalakan liar. Perkembangan dari kegiatan tersebut sampai saat ini dirasakan cukup lambat karena kesepakatan yang dibuat adalah dengan Bagian Kehutanan Negara Cina (Chinese State Forest Administration) yang memiliki tanggung jawab terhadap isu-isu kehutanan domestik. Kesepakatan ini diperkirakan akan berjalan dengan lebih baik apabila dilakukan dengan Instansi Umum Cina (China Custom Agency) yang memiliki kewajiban dalam hal penyaringan produk-produk impor. Walaupun demikian, selama pertemuan bisnis kepemimpinan (Business Leadership Meeting) untuk pembalakan liar di Hong Kong, Indonesia dan Cina mengadakan pertemuan terpisah untuk membicarakan kesepakatan-kesepakatan yang harus diambil sebagai bentuk kerjasama lebih lanjut. Sebagai upaya tindak lanjut, TNC mengambil inisiatif untuk memfasilitasi kunjungan informal oleh SFA ke Indonesia pada akhir 2006, yang akan dilanjutkan dengan konferensi tentang pembalakan liar di Beijing pada tahun 2007 mendatang.

Pengaruh Cina terhadap kondisi kehutanan di Indonesia mungkin akan sangat bergantung pada besarnya porsi impor Cina terhadap produk perkayuan dari Indonesia, yang nantinya akan diolah dan di ekspor kembali ke pasar dengan lebih memperhatikan kebutuhan pasar akan pelestarian lingkungan. Amerika Serikat, Jepang dan Hong Kong adalah importir utama produk perkayuan Cina, dengan dukungan Uni Eropa yang terus meningkatkan peran pentingnya. Ekspor ke Amerika Serikat dan negara-negara anggota Uni Eropa mengalami peningkatan yang cukup berarti sejak tahun $1997 .{ }^{20}$ Sejak, hampir keseluruhan kayu meranti dengan kualitas utama yang berasal dari Indonesia diolah di Cina dan produknya dipasarkan ke pasar internasional, sebagian besar kayu Indonesia yang datang ke Cina baik secara legal maupun illegal diperuntukkan untuk tujuan ekspor ulang.

${ }^{20}$ White et al. 2006. 


\subsection{Pembelajaran dari kondisi permintaan terhadap produk kayu yang lestari dari Indonesia}

Kebutuhan pasar akan produk hutan yang bersertifikat dan legal dipicu oleh beberapa faktor, termasuk di dalamnya adalah kebijakan pembelian dari perusahaan dan kebijakan pemerintah terkait dengan peraturan impor. Berdasarkan pengalaman yang diperoleh dari hasil kegiatan Aliansi menyatakan bahwa proses di pemerintahan mengambil peran yang sangat penting dalam peningkatan kebutuhan akan produk hutan yang lestari dari Indonesia. Prosesproses ini memiliki pengaruh yang besar terhadap permintaan baik secara langsung maupun tidak langsung:

- Pengaruh langsung terhadap kebijakan pembelian publik yang mempengaruhi penggunaan kayu pada proyek konstruksi publik. Pada beberapa negara, hal ini menggambarkan besarnya impor produk perkayuan dari Indonesia. Kebijakan pembelian publik yang mensyaratkan penggunaan kayu legal atau kayu dengan sumber yang lestari untuk kontrak-kontrak konstruksi publik mengakibatkan banyaknya perusahaan mencari sumber kayu yang legal dan berasal dari sumber yang lestari. Pemerintah Inggris, Belanda dan Belgia memiliki persyaratan yang ketat untuk dalam aspek legalitas dan kelestarian dari produk kayu yang digunakan pada kontrak-kontrak mereka. Hal ini menggambarkan adanya persyaratan pembelian publik telah berpengaruh besar terhadap pasar kayu Indonesia dan sangat mungkin untuk berkembang.

- Pengaruh tidak langsung terhadap larangan perdagangan produk kayu dari sumber ilegal, dimana peraturan-peraturan tersebut berpengaruh terhadap pembeli swasta dan publik secara bersamaan. Sebagai usaha untuk merespon kebijakan pembangunan dan mempromosikan kegiatan lebih lanjut, Aliansi telah bekerja sama dengan pemerintah di negaranegara importir.

Tidak ada keterangan mengenai kebijakan pembelian dari perusahaanperusahaan selain pemenuhan terhadap persyaratan kontrak pengadaan oleh publik. Para pembeli mencari kayu yang dapat memberikan bukti legalitas atau kelestarian sumbernya dapat juga dialihkan pada pemasok kayu dengan resiko yang lebih rendah, atau melakukan tekanan terhadap para pemasok mereka untuk melakukan sertifikasi atau verifikasi legalitas. Beberapa perusahaan Eropa dan Amerika Utara telah memilih untuk mengalihkan pembelian dari Indonesia sebagai akibat dari tekanan LSM lokal. Mengingat 
sebagian besar produk perkayuan dari Indonesia dapat digantikan dengan produk perkayuan dari negara lain, banyak perusahaan memelihara reputasi mereka di bidang lingkungan dengan memilih pemasok dari negara-negara yang memiliki kontroversi rendah. Sebagai contoh, berkaitan dengan skorsing FSC terhadap Perhutani, banyak pedagang Jerman mengalihkan pembelian furnitur ke bahan Eucalyptus yang memiliki sertifikasi dari FSC di Amerika Latin. Hal ini juga terjadi setelah kampanye Greenpeace di tahun 2004, empat pembeli besar produk perkayuan dari Indonesia di Inggris menghentikan pembelian kayu dari Indonesia. ${ }^{21}$ Saat ini B\&Q membeli melakukan pembelian plywood dalam skala besar dari Brasil dan Travis Perkins, pembeli utama untuk kayu tropis, mengalihkan pembeliannya dari Indonesia ke Ghana yang memiliki sumber kayu legal yang terverifikasi. ${ }^{22}$

Meskipun demikian, beberapa perusahaan memilih untuk tetap berhubungan dengan pemasok dari Indonesia. WWF dan TFT telah membantu beberapa perusahaan melalui jaringan pemasaran perusahaan-perusahaan di Indonesia guna mendapatkan sertifikasi dari FSC untuk produk dasar yang mereka hasilkan. Sebagai contoh, WWF telah bekerja sama dengan BlueLink dan Lowe's Companies di Amerika Serikat untuk identifikasi HPH-HPH di Indonesia yang memiliki potensi untuk mendapatkan sertifikasi dari FSC, sementara TFT aktif membangun jaringan yang menghubungkan antara anggota pemasok Indonesia dan anggota produsennya.

\subsection{Hubungan Permintaan dan Penawaran}

\subsubsection{Pengiriman sinyal pasar ke perusahaan pengelolaan hutan}

Salah satu halangan terbesar dalam pengiriman sinyal pasar ke pengelola hutan dapat dilihat dari kondisi perdagangan kayu yang terkadang tidak menentu dan melibatkan perantara menengah dan perantara atas dalam jumlah yang cukup banyak. Adanya struktur yang berlapis-lapis dalam perdagangan kayu mengakibatkan perusahaan sulit untuk mengetahui apakah pasokan kayu mereka berasal dari sumber yang legal dan hal ini memberikan implikasi terhadap pedagang yang peduli terhadap aspek legalitas dan kelestarian sumber kayu mereka.

\footnotetext{
${ }^{21}$ RIIA 2004.

${ }^{22}$ Steve Crewe, personal communication.
} 
Bisnis perdagangan kayu bulat, kayu gergajian, industri lanjutan, agen atau pedagang produk kayu jadi, secara agresif menjaga informasi aliran pasokan mereka supaya tidak tersisih dari pasar. Hal ini mengakibatkan pembeli sulit untuk mengubah persyaratan pasar mereka secara langsung ke sumber Perusahaan Pengelolaan Hutan (Forest Management Enterprise - FMEs) dan sebagai dampak langsung terbesar dari kondisi pasar tersebut mereka alihkan ke perusahaan. Berkaitan dengan kondisi tersebut, perusahaan menjadi jaringan yang sangat penting dalam rantai penyediaan selama mereka mampu melakukan kontrol terhadap penggunaan kayu pada produk mereka dan memberikan isyarat pasar dari pembeli ke pemasok material dasar.

Banyaknya Perusahaan Pengelola Hutan Indonesia yang beroperasi secara mandiri/terpisah dari perusahaan hilir, mengakibatkan tidak cukupnya insentif untuk Perusahaan Pengelola Hutan dalam memenuhi kebutuhan pasar. Meskipun perusahaan tersebut terintegrasi secara vertikal, FME akan tetap mencari penawaran tertinggi dari pada menjual secara eksklusif ke industri asosiasinya. FME memilih untuk tidak melakukan investasi sertifikasi hingga perusahaan memberikan insentif langsung untuk kegiatan tersebut.

Lebih lanjut, terdapat beberapa jaringan dalam rantai pasokan kayu di luar perusahaan dari pedagang pengecer. Sebagai contoh, hubungan perdagangan internasional yang umum dilakukan di bidang perkayuan adalah:

- Penjualan dengan kontrak langsung ke pelanggan (customer), meskipun melalui kantor pemasaran atau agen: hal ini umum terjadi pada perdagangan untuk penjualan ke Eropa daratan;

- Penjualan ke para pedagang (trader), sebagian besar terjadi di Singapura dan Hong Kong; dan

- Penjualan untuk perwakilan perusahaan asing yang melakukan pembelian secara langsung. ${ }^{23}$

Di Inggris, tidak seperti di negara Eropa lainnya, agen perkayuan memiliki peran penting dalam penentuan peraturan impor kayu. Agen-agen tersebut menangani pemesanan dari perusahaan dan pedagang dan melakukan pencarian terhadap pemasok kayu yang dapat membuktikan bahwa kayu tersebut sesuai dengan persyaratan yang telah ditentukan. Hingga tahun 1980an, agen-agen tersebut melakukan impor untuk sebagian besar kebutuhan kayu di Inggris tetapi kemudian

${ }^{23}$ ITTO 2003. 
sebagian besar perusahaan mulai melakukan impor langsung dari sumber-sumber mereka sendiri. ${ }^{24}$

Wilayah perdagangan Jepang atau Sogo Soshas, memiliki peran penting dalam distribusi kayu tropis. Sogo Soshas melakukan pembelian panel domestik dan impor hingga 70\%. Mereka berkeinginan untuk mencapai skala global dan mendominasi seluruh industri ekspor impor. Beberapa Sogo Soshas terintegrasi secara vertikal terhadap beberapa aspek perdagangan kayu tropis. ${ }^{25}$ Cabang perusahaan dari Marbeni, Itochu, Sumitomo Corporation, Sumitomo Forestry dan Sojitzu mengambil peran dalam pembelian plywood dari Indonesia. ${ }^{26}$ Mereka membeli plywood untuk dijual kembali ke penjual yang menjual kembali hampir 95\% produk tersebut untuk proses lanjutan dan distribusi ulang. ${ }^{27}$

Seiring dengan runtuhnya jaringan pemasaran APKINDO pada tahun 1998, perusahaan plywood harus melakukan pencarian pasar mereka sendiri dan untuk kepentingan pemasaran langsung dari para pedagan berkembang dengan sangat baik. Penjualan ke pedagang mungkin hanya mengambil seperempat bagian dari ekspor plywood Indonesia. Penjualan ke Timur Tengah sebagian besar dimonopoli oleh pedagang dari Singapura, penjualan ke Cina kadang-kadang diambil oleh pedagang-pedagang yang berpusat di Hong Kong dan penjualan ke Amerika kadang-kadang dilakukan melalui rumah dagang Jepang. Beberapa pengguna akhir, seperti perusahaan konstruksi dan perusahaan furniture besar di Jepang dan Eropa, meningkatkan peran mereka dalam menciptakan jaringan pasar langsung ke produsen untuk memotong aliran dari perusahaan importer tradisional. ${ }^{28}$

Hasil dari rantai pasokan yang tidak transparan mengakibatkan importir-importir melakukan pengkajian kembali terhadap sumber kayu mereka dan mencoba menjembatani kekosongan informasi antara mereka dengan hutan (sumber bahan baku). Kondisi ini sangat berarti bagi perusahaan-perusahaan di Indonesia yang telah bekerja sama dengan organisasi seperti WWF FTN, Tropical Forest Foundation (TFT) dan Tropical Forest Trust (TFT) untuk melakukan identifikasi terhadap sumber kayu yang legal dan lestari.

\footnotetext{
${ }^{24}$ Gale 1998.

${ }^{25}$ Cashore et al. 2004.

${ }^{26}$ Mutai Hashimoto, personal communication.

${ }^{27}$ ITTO 2005.

${ }^{28}$ ITTO 2005.
} 


\subsubsection{Insentif untuk perusahaan-perusahaan Indonesia}

Seiring dengan hadirnya produk pengganti yang murah untuk produk kayu dari Indonesia dalam skala besar, hal ini memungkinkan bahwa kebanyakan dari biaya tambahan untuk legalitas dan pengelolaan kayu yang lestari sepertinya harus ditanggung oleh FMEs dengan dukungan perusahaan dan industri hilir lainnya dalam rantai penyediaan. Berdasarkan pernyataan ITTO, "kondisi pasar dimana kayu-kayu tropis tidak dapat digantikan dan unik sangat terbatas, dan karenanya harga produk harus diatur pada tingkat yang tepat untuk menjaga kompetensinya dengan produk yang lain, tidak hanya produsen kayu tropis yang lain." ${ }^{29}$ Adanya penggantian produk kayu ke produk non kayu seperti plastik dan baja, yang terus meningkat, menjadikan pasar tidak memungkinkan menyerap setiap peningkatan harga yang berarti.

Insentif yang diberikan kepada perusahaan-perusahaan Indonesia untuk pengelolaan hutan lestari akan memungkinkan mereka untuk mempertahankan atau memelihara akses ke pasar yang lebih stabil yang menawarkan kondisi perdagangan yang cukup baik. Fakta menunjukkan bahwa pasar Eropa dan Jepang adalah pasar yang sangat penting bagi eksportir produk perkayuan Indonesia. Pada April 2004, Uni Eropa mengeluarkan persyaratan struktur plywood untuk kekuatan dan peraturan keselamatan ("CE marking"), dan mengacu pada keterangan APKINDO, banyak perusahaan plywood Indonesia bersedia untuk memenuhi persyaratan tersebut sebagai usaha untuk memelihara akses pasar ke Uni Eropa. ${ }^{30}$ Adanya kenyataan bahwa sebagian besar HPH telah berupaya untuk mendapatkan sertifikasi mengindikasikan bahwa terdapat kemungkinan untuk meningkatkan keuntungan dari akses pasar yang berkelanjutan. Terdapat juga anekdot yang menyatakan bahwa Cina sepertinya bukan pasar yang menarik, seiring dengan rendahnya harga dan kurangnya praktisi bisnis yang ramah dibandingkan dengan Eropa dan Jepang.

Kelanjutan akses ke pasar Eropa dan Amerika Utara sangat penting bagi produsen Indonesia karena pencarian pasar baru dapat meningkatkan biaya yang cukup signifikan. Produser Indonesia berusaha untuk memelihara hubungan bisnis jangka panjang dengan dua alasan. Pertama, transaksi bisnis Indonesia terkait erat dengan hubungan personal yang memerlukan waktu untuk membangunnya. Kedua, nilai dari hubungan-hubungan tersebut akan terus meningkat selama perusahaan dapat menyesuaikan teknologi prosesing yang digunakan untuk

${ }^{29}$ ITTO 1999.

${ }^{30}$ APKINDO, personal communication. 
memenuhi kebutuhan spesifik dari pembeli, dan membuat mereka memproduksi produk dengan nilai tambah yang tinggi.

Potensi keuntungan finansial lain yang diperoleh produsen dari pemenuhan persyaratan pasar akan aspek lingkungan adalah bahwa hal ini mungkin akan memperpendek rantai pasokan oleh pasar. Hasil pekerjaan yang dilakukan oleh WWF GFTN telah membuktikan bahwa pembeli produk perkayuan Indonesia di Eropa dan Amerika Utara sering menemui rantai pasokan yang cukup kompleks dan terkadang tidak peduli dengan sumber kayu yang mereka beli. Kepedulian pembeli terhadap aspek lingkungan meningkatkan pemahaman akan perlunya biaya terhadap rantai pasokan mereka untuk menghindari resiko dari kayu illegal atau kayu dengan sumber yang meragukan masuk ke dalam rantai pasokan mereka. Pada beberapa kondisi, pembeli berusaha untuk mengadakan kontak dengan FMEs Indonesia yang memiliki potensi untuk mengeluarkan verifikasi legal atau kayu dengan sertifikasi dari FSC. Hal ini menjadi potensi besar untuk mendapatkan keuntungan bagi perusahaan, selama mereka dapat menangkap pendapatan yang selama ini menjadi biaya transaksi yang diambil oleh perantara dalam rantai pasokan. Hal ini sangat relevan untuk FMEs dalam skala kecil yang tidak memiliki akses langsung ke pasar luar negeri.

\section{Insentif untuk Jaringan Pasar Langsung: Hutan Jati Rakyat}

Pada produsen jati skala kecil, kemungkinan untuk akses langsung ke pasar akan menjadi insentif terbesar untuk sertifikasi. Produsen skala kecil yang mengelola blok jati dengan ukuran antara satu hingga sepuluh hektar memiliki akses pasar yang terbatas secara individu di bawah pedagang perantara yang mengambil untung jauh lebih besar. WWF bersama dengan partner sedang membangun jaringan pemasaran antara masyarakat di Wonogiri dan pembeli dari Belanda, yang memiliki ketertarikan cukup kuat dalam kemitraan jangka panjang dengan dua kelompok masyarakat. Melalui kegiatan ini dilaporkan bahwa Wonogiri seharusnya dapat memperoleh harga lebih dari dua kali lipat dari harga yang mereka terima sebelumnya.

Pada skema yang sama dengan dukungan dari TFT di Sulawesi Selatan, kayu jati dari hutan yang mendapatkan sertifikasi pengelolaan hutan oleh koperasi masyarakat dari FSC akan dijual langsung ke perusahaan anggota TFT di Indonesia yang membatu keuangan proyek. ${ }^{31}$

${ }^{31}$ FSC Press Release, Geneva, May 24th 2005. http://www.tropicalforesttrust.com 


\section{Insentif untuk PT. Sumalindo Lestari Jaya untuk Mengikuti Sertifikasi}

PT Sumalindo Lestari jaya (SLJ) adalah produsen plywood dan mixed density fiberboard (MDF) terintegrasi yang berlokasi di Kalimantan Timur. Konsesi SLJ unit II telah mendapatkan sertifikasi dari LEI-FSC pada Januari 2006. Wilayah konsesi mereka terletak di kabupaten Kutai Barat dan kabupaten Malinau di propinsi Kalimantan Timur dengan total area 269.660 ha. Pada Februari 2006, SLJ II menjadi HPH pertama yang bergabung dengan WWF FTN Indonesia, Nusa Hijau.

Sumalindo memiliki beberapa alasan untuk melakukan sertifikasi. Sebagai perusahaan publik Sumalindo diharuskan untuk beroperasi dalam kondisi transparan dan praktek bisnis yang legal. Hal ini juga berkaitan dengan nilai persediaan SLJ dan kapasitas pinjaman yang tergantung pada kemampuan pengembalian keuntungan di masa mendatang, yang sangat bergantung pada kelestarian ketersediaan kayu yang dapat disediakan oleh SFM. Sumalindo bersaing dengan empat perusahaan publik lain yang terkait dengan sektor kehutanan di Indonesia dan strategi yang diterapkan telah mengantarkannya menjadi perusahaan global dengan citra yang terkenal. Bagian ini menjelaskan mengapa Sumalindo berusaha untuk mengambil bagian utama dalam kelompok kelestarian. Perusahaan ini telah mendapatkan tekanan dari pemerintah untuk meningkatkan kinerjanya dan lolos atas audit yang dilakukan pemerintah pada tahun 2004. Potensi keuntungan tambahan dari sertifikasi di Sumalindo adalah kemungkinan untuk menjual kayu dengan sertifikasi ke perusahaan furnitur yang sedang mencoba untuk menggunakan bahan baku dari kayu rimba campuran sebagai pengganti kayu jati bersertifikat.

Sertifikasi Sumalindo telah meningkatkan ketertarikan beberapa importir plywood utama di Inggris yang melihat hal ini sebagai validasi untuk tetap berhubungan dengan sektor perkayuan di Indonesia. Perusahaan-perusahaan ini telah menyatakan keinginannya untuk tetap melakukan pembelian dari Sumalindo di masa mendatang. ${ }^{32}$

${ }^{32}$ George White, personal communication. 


\subsection{Pembelajaran pada ketersediaan produk kayu yang lestari dari Indonesia}

Perusahaan-perusahaan di Indonesia memiliki respon yang kurang terhadap kebutuhan pembeli yang tidak melakukan perdagangan dengan mereka karena adanya biaya yang cukup besar dan resiko terkait dengan pengalihan pasar dan perolehan keuntungan yang belum jelas. Meskipun apabila pembeli menawarkan harga yang cukup tinggi, perusahaan tidak dapat merespon dengan mudah. WWF dan TNC mendapatkan pengalaman bahwa sebagian besar produsen plywood, termasuk Sumalindo, telah memiliki hubungan jangka panjang dengan pembeli yang tidak akan menimbulkan resiko terhadap mereka. Hal ini dikarenakan biaya yang dikeluarkan untuk membentuk jaringan pasar baru akan berpengaruh terhadap pasokan ke pembeli yang ada dalam hubungan bisnis saat ini. Saran yang diberikan dalam hal ini adalah, bahwa terbentuknya pasar berdasarkan pendekatan konservasi akan berjalan dengan sukses apabila pembeli terus melakukan hubungan baik dari pada memboikot produk perkayuan Indonesia.

Beberapa anggota WWF GFTN telah menghentikan pembelian kayu dari Indonesia dan hal tersebut sepertinya akan menjadi penghalang bagi Nusa Hijau untuk mempromosikan sertifikasi. Aliansi telah merespon hal tersebut dengan mendorong perusahaan-perusahaan yang masih memiliki hubungan bisnis dengan Indonesia untuk tetap berhubungan. Sebagai contoh, WWF melalui GFTN, telah mendukung perusahaan seperti BlueLink dan Lowe's Companies untuk tetap bekerja sama dengan supplier mereka saat ini. Pada sisi lain, TNC telah bekerja sama dengan federasi perdagangan kayu di Eropa untuk mendorong mereka agar tetap berhubungan dengan Indonesia. Pendekatan yang dilakukan oleh Aliansi untuk sertifikasi, termasuk didalamnya adalah verifikasi legalitas, menjadi komponen kunci dari strategi untuk menghadapi tantangan sertifikasi di Indonesia dengan mengajak pembeli yang sensitif terhadap isu lingkungan untuk mendukung perkembangan program tersebut.

Faktor lain, selain dari harga dan kerangka waktu yang ingin diketahui oleh perusahaan dalam jaringan pasar adalah kelas produk yang diakomodir dalam kemitraan. Seiring dengan semakin banyaknya pabrik yang beroperasi di bawah kapasitas industri karena keterbatasan bahan baku, mereka perlu memaksimalkan keuntungan untuk setiap meter kubik kayu bulat. Hal ini berarti bahwa pabrik memerlukan pasar untuk produk dengan kualitas kelas dua dan kelas tiga, dan lebih memilih untuk memperoleh pembeli yang kurang spesifik dengan 
keperluannya. Berdasarkan hal tersebut, faktor-faktor yang mungkin membatasi respon permintaan pembelian pasar berdasarkan yang disediakan oleh WWF GFTN adalah kecenderungan dari kelas spesifikasi yang rendah. Beberapa permintaan pembelian tersebut sesuai untuk pedagang besar dan broker kayu yang melakukan kesepakatan dengan pembeli tradisional di Eropa dan Amerika Utara, yang kemungkinan mereka tidak sesuai untuk pabrik palywood yang sedang mencari pasar untuk keseluruhan produknya.

Pilihan pembeli terhadap kayu legal dan lestari seringkali "tidak terinformasikan dengan baik" dari konsumen di rantai pasokan akhir melalui perantara terhadap sumber FME. Seperti pada diskusi sebelumnya di bagian 3.2 dan 3.2.2 adanya lapisan dalam struktur perdagangan kayu menyulitkan perusahaan untuk mengetahui apakah bahan baku mereka berasal dari sumber yang legal dan lestari.

WWF merekomendasikan pembeli untuk meminta pemasok mereka menyertakan informasi terverifikasi mengenai sumber kayu dalam produk mereka. Apabila pemasok hendak menghindari kesalahan pemberian informasi terhadap pembeli mereka, maka mereka perlu melakukan pemeriksaan lebih lanjut terhadap rantai pasokan mereka sendiri. Berdasarkan teori, hal ini harusnya menjadi hasil dari kegiatan lacak balak ke sumber kayu di hutan seiring dengan adanya kesamaan pertanyaan yang dilontarkan oleh rantai pasokan secara berturut-turut mengenai sumber kayu, apakah berasal dari hutan yang dikelola dengan baik atau legal. Meskipun demikian, pada prakteknya pedagang perantara sering kali menutupnutupi informasi mengenai hal tersebut karena ketakutan akan kompetisi, atau bahkan memberikan informasi yang berlebihan kepada konsumen tentang resiko apabila terjadi pemutusan terhadap rantai pasokan mereka. Hasilnya adalah bahwa spesifikasi terkait dengan kewajiban terhadap sumber pada bagian akhir rantai pasokan seringkali tidak dikomunikasikan dengan baik pada sebagian besar permulaan rantai.

Perusahaan memerlukan transparansi dasar dalam rantai pasokan mereka sebagai dasar untuk mencari integrasi vertikal terbesar untuk mengurangi jumlah jaringan yang harus dilalui oleh sumber kayu. Apabila kecenderungan ini terus berlangsung, agen kayu akan menghadapi resiko tekanan, atau mungkin inventori ulang terhadap diri mereka sendiri sebagai agen dengan "kewajiban pencari kayu". 
Kelemahan pemerintah di bidang kehutanan merupakan penghalang bagi investasi pengelolaan hutan lestari di Indonesia. Pada sebagian besar HPH terdapat kesenjangan yang cukup besar antara praktek kehutanan yang saat ini dilakukan dengan hal-hal yang menjadi persyaratan dalam skema sertifikasi LEI atau FSC. Tidak seperti praktek kehutanan di Eropa dan Amerika Utara dimana sertifikasi pengelolaan hutan lestari lebih diutamakan pada norma industri, sebagian besar praktek kehutanan di Indonesia dilakukan dengan tidak lestari dan bahkan ilegal. Karenanya, perubahan yang signifikan di bidang praktek operasional sangat diperlukan untuk mencapai sertifikasi di Indonesia, dengan kebutuhan waktu yang signifikan serta investasi modal.

Praktek pembalakan liar dalam skala luas juga memiliki implikasi penting dalam pelaksanaan sertifikasi. Ketersediaan kayu yang dipanen tanpa dilengkapi dengan pembayaran royalti dan pajak akan memicu terjadinya penurunan harga kayu di pasar dan mengurangi investasi jangka panjang di bidang kehutanan dan pengelolaan hutan. Adanya pembalakan liar yang tidak terkontrol dalam pengusahaan hutan juga dapat menjadi penghalang pengusahaan hutan tersebut untuk mendapatkan sertifikasi. Hal ini dapat menimbulkan masalah apabila penebang liar atau masyarakat terlibat dalam kegiatan pembalakan liar tersebut.

Isu-isu di pemerintahan lainnya yang dapat menghalangi perkembangan sertifikasi adalah ketidakpastian iklim bisnis di sektor kehutanan. Setelah era Soeharto kehilangan kekuasaannya, pemerintahan di bidang kehutanan mengalami perubahan drastis dari sentralisasi menjadi desentralisasi dan kembali lagi pada kontrol sentralisasi. Sektor ini masih dalam proses pengaturan, dan perusahaan perkayuan banyak mengajukan keberatan mengenai kesenjangan dalam hal transparansi dan prediksi mengenai kebijakan kehutanan yang saat ini dijalankan. Sebagai contoh, pada kebijakan 'soft landing', Departemen Kehutanan memutuskan jatah tebang tahunan untuk skala Indonesia dalam jumlah yang sangat rendah dibandingkan dengan kebutuhan material kayu legal yang ada. Perusahaan-perusahaan mitra kerja TNC menghadapi permasalahan dalam hal perpanjangan ijin tebang dengan alasan yang tidak jelas. Sebagai contoh PT Daisy Timber harus dikeluarkan dari uji percontohan lacak balak karena adanya jeda waktu dalam persetujuan Rencana Pengelolaan Tahunan (RKT) dari Dinas Kehutanan propinsi.

Berdasarkan hal tersebut di atas, insentif utama untuk mencapai sertifikasi di Indonesia mungkin dapat dicapai dengan mengurangi kuota tebang dan pendampingan lainnya atau insentif dari Departemen Kehutanan untuk 
perusahaan pengusahaan hutan yang memperoleh sertifikasi. Berdasarkan hal-hal tersebut, Sumalindo telah memperoleh perpanjangan ijin pengelolaan pengusahaan di luar kebiasaan untuk kembali mendapatkan sertifikasi dari FSC. Insentif dari pemerintah di berbagai sisi dapat menjadi pemicu utama sertifikasi di Indonesia, berdasarkan kasus Sumalindo yang memperoleh perpanjangan ijin pengusahaan di luar kebiasaan, dan tidak berhubungan dengan usaha mereka untuk mencapai sertifikasi. Walaupun demikian, Aliansi menemukan adanya dukungan penting dari pemerintah untuk sertifikasi dan WWF Nusa Hijau berharap untuk melakukan fasilitasi lobi untuk mendapatkan insentif dari pemerintah bagi para anggotanya. Terkait dengan hal tersebut, TNC, WWF dan Organisasi Keuangan Internasional (IFC) sedang melakukan studi mengenai aturan dalam insentif pemerintah untuk mempromosikan sertifikasi. Studi dilakukan dengan identifikasi kemungkinan insentif yang dilakukan oleh Aliansi ke Departemen Kehutanan. 


\section{Pembelajaran dalam Promosi Verifikasi Kayu Legal}

\subsection{Penentuan 'Kayu Legal'}

Beberapa importer kayu Indonesia memiliki perhatian lebih pada sisi legalitas karena mereka melihat hal ini sebagai langkah awal menujukelestarian sumber bahan baku kayudari pada sebagai sebuah tujuan akhir. Pada beberapa pemain pasar besar di sektor swasta, motivasi untuk mencari pemasok kayu legal lebih dipengaruhi oleh kampanye yang dilakukan oleh LSM yang melawan mereka dan/atau mitra kerjanya. Hal ini menjadikan perusahaan-perusahaan tersebut secara prinsip memiliki perhatian terhadap konsesi standarisasi legalitas yang diadopsi oleh LSM tersebut. Peran penting dalam perencanaan standar yang memiliki konsensus antara para pihak di Indonesia dilakukan oleh TNC melalui koordinasi dengan UK-RI MoU sebagai proses untuk melawan pembalakan liar. Berdasarkan pada komunitas aktivis para pihak, keberadaan kayu legal dari Indonesia menjadi sangat sulit. Hal ini karena produk hukum yang direncanakan untuk melindungi hak masyarakat di sekitar hutan diabaikan pada saat hak pengusahaan hutan diberikan kepada perusahaan perkayuan. Sebagian besar area hutan di Indonesia didiami oleh masyarakat adat dan atau lokal, dan sebagian besar perusahaan perkayuan menyertakan masyarakat tradisional, atau adat, menuntut areal hutan tersebut. Hasil studi yang dilakukan ICRAF dan WALHI menunjukkan adanya sedikit, jika ada, HPH yang dapat membuktikan keberadaannya berdasarkan persyaratan hukum yang ada. Khususnya berdasarkan ketentuan yang terkait dengan deliniasi hutan negara dan areal $\mathrm{HPH}$, serta keterlibatan konsultasi masyarakat yang jarang diikutsertakan dalam dokumen yang ada. Pada kenyataannya, diperkirakan hanya $10 \%$ dari areal hutan negara yang dideliniasi dengan baik dan benar oleh Departemen Kehutanan, dan penebangan yang dilakukan pada $90 \%$ areal lainnya secara teknik dilakukan secara illegal. Persentase dari HPH yang ada berdasarkan lembaran resmi Departemen Kehutanan dengan zona hutan negara bahkan mungkin lebih rendah.

Berdasarkan alasan-alasan tersebut, fokus legalitaskayu dari Indonesia masih kontraproduktif. Mereka berpendapat bahwa kayu legal terverifikasi akan diterima oleh 
kalangan luas sama seperti kayu yang lestari. Mereka mengutip hasil penelitian yang menunjukkan bahwa sistem TPTI tidak cukup untuk melindungi fungsi lingkungan yang diberikan oleh hutan. Mereka juga memberikan argumentasi bahwa dari sisi sosial, penerimaan legalitas kayu yang dipanen dengan mengikuti aturan dan ketetapan yang ada, berarti mengesahkan kerangka legalitas yang telah memarjinalkan masyarakat di sekitar hutan, dan mungkin memiliki kontribusi dalam pelanggaran hak asasi manusia, terutama untuk produk hukum dalam proses reformasi yang diawali dengan jatuhnya era Soeharto. Secara kebetulan ketetapan-ketetapan yang dibuat antara struktur pemerintah mengenai standar legalitas mendukung perubahan proses dan secara aktif mendorong pemeliharaan standar tersebut sesuai dengan reformasi hukum/peraturan.

\subsubsection{Inggris-RI MoU Standar Legalitas}

Sertifikasi hutan, seperti yang dipromosikan oleh FSC dan institusi lainnya, dilakukan untuk menyediakan informasi prinsip mengenai kelestarian kepada konsumen, dengan berdasar pada pemenuhan persyaratan legal dari perusahaan pengelolaan hutan. TNC telah melakukan usaha selama lebih dari tiga tahun, dengan berkolaborasi dengan $\mathrm{DFiD}$, untuk merancang standar legalitas bersama untuk Indonesia, seperti kemungkinan penerapan sistem lacak balak dan verifikasi yang dapat diaplikasikan di lapangan.

$\mathrm{MoU}$ antara Inggris-RI untuk melawan pembalakan liar, yang ditandatangani pada April 2002, dilengkapi dengan rencana kegiatan yang mencakup penegasan mengenai pembalakan liar sebagai agenda utama. Butir pertama dan ketiga (A1 dan A3) pada rencana kegiatan dalam MoU memiliki hubungan langsung dengan definisi dari pembalakan liar:

- Adopsi definisi kerja tentang pembalakan liar.

- Mengkaji ulang mengenai hutan dan kehutanan terkait dengan perundangundangan, termasuk peraturan desentralisasi, konstitusi, perundangan kehutanan, peraturan, regulasi, ketetapan-ketetapan, peraturan perdagangan dan transportasi.

Sebagai hasilnya, DfID Inggris melalui tim konsultan melakukan pengkajian ulang mengenai penerapan hukum di Indonesia, dan selanjutnya bekerja sama dengan TNC untuk menyusun standar legalitas dan sistem lacak balak kayu untuk Indonesia. TNC dengan tim konsultan URS/SGS melakukan konsultasi dengan para pihak dari berbagai kalangan melalui wawancara, kuisioner dan workshop berkala di tingkat kabupaten, provinsi dan nasional, para pengusaha 


\section{Box 1. Prinsip Legalitas untuk Praktek Kehutanan dan Industri Perkayuan di Indonesia}

"Kayu disebut legal apabila validitas asalnya, ijin tebang, sistem dan prosedur pemanenan, dokumentasi administrasi dan transportasi, proses, dan perdagangan atau pengirimannya dapat memenuhi persyaratan legal yang diperlukan".

\section{Prinsip 1. Kepemilikan Lahan dan Hak Penggunaan}

Status legal dan hak kepemilikan unit pengelolaan hutan dapat didefinisikan secara jelas dan batasnya telah disahkan dengan jelas melalui dokumen negara. Perusahaan yang terdokumentasi, memiliki hak secara legal untuk melakukan pemanenan hutan dalam batas-batas yang telah ditentukan, dan hanya melakukan pemanenan pada batas-batas tersebut.

\section{Prinsip 2. Dampak Fisik dan Sosial Lingkungan}

Perusahaan memiliki Analisis Dampak Lingkungan (AMDAL) yang mencakup unit pengelolaan hutan yang disusun pada proses perencanaan, dan secara umum dapat memenuhi persyaratan legal, fisik, sosial dan lingkungan dalam AMDAL, seperti persyaratan yang diperlukan dalam kegiatan pengawasan dan pelaporan dari pelaksanaan AMDAL.

\section{Prinsip 3. Hubungan Kemasyarakatan dan Hak Ketenagakerjaan}

Perusahaan dilengkapi dengan kewajiban legal dalam menjamin peningkatan kualitas hidup masyarakat yang terkena dampak kegiatan dalam cakupan unit pengelolaan hutan, sebagai persyaratan untuk pelayanan terhadap masyarakat lokal, dan tingkat kehidupan serta keselamatan kerja dari para pekerja dalam unit pengelolaan hutan.

\section{Prinsip 4. Peraturan dan Perundangan Pemanenan Hutan}

Perusahaan melakukan perencanaan hutan, pemanenan dan kegiatan lain dalam unit pengelolaan hutan memenuhi semua persyaratan dalam peraturanperaturan pemerintah.

\section{Prinsip 5. Pajak Kehutanan}

Perusahaan membayar seluruh kewajiban, royalti, pajak-pajak dan biaya-biaya legal lainnya terkait dengan unit pengelolaan hutan dan daerah asal kayu yang dipanen.

\section{Prinsip 6. Identifikasi kayu, Pemindahan dan Pengiriman}

Perusahaan memastikan bahwa transportasi kayu dari unit pengelolaan hutan dapat diidentifikasi secara jelas, memiliki dokumen terkait yang benar dan dilakukan berdasarkan peraturan pemerintah yang ada.

\section{Prinsip 7. Proses dan Pengiriman Kayu}

Fasilitas prosesing kayu dan perusahaan pengiriman memiliki ijin yang jelas dan dijalankan dengan berdasarkan peraturan pemerintah yang berlaku. 
kehutanan dan masyarakat sekitar hutan, seperti perwakilan LSM, organisasi kemasyarakatan, akademisi dan pengamat kehutanan serta institusi internasional lainnya. Berdasarkan hasil konsultasi tersebut, draft laporan tentang penentuan definisi legalitas disajikan oleh tim URS/SGS kepada TNC pada November 2003. Definisi legalitas ini kemudian dijabarkan dalam tujuh prinsip yang mencakup kriteria dan indikator seperti tertera dalam Box 1.

Berdasarkan publikasi draft standar legalitas, jelas bahwa standar kepemilikan sangat diperlukan di Indonesia sehingga TNC memutuskan untuk mengadopsi peran yang kurang penting dalam proses. Standar tersebut secara umum diambil alih oleh LEI untuk dikembangkan dengan fasilitas dari komite pengarah (steering committee) untuk pengembangan standar lebih lanjut, yang secara khusus diserahkan pada kelompok kerja untuk melakukan interpretasi professional dari peraturan yang ada untuk pengembangan standar dalam versi selanjutnya.

\subsubsection{Manual "Penetapan legalitas" dari WWF}

Pada proses penyusunan manual "Penetapan legalitas", WWF menemukan bahwa perusahaan-perusahaan perlu menyeimbangkan kerangka isu perhatian legalitas oleh para pihak dengan keperluan biaya audit. Pendekatan komprehensif untuk penentuan legalitas produk kehutanan dapat mencakup beberapa isu di luar sektor kehutanan (sebagai contoh, ketaatan dalam bidang hukum terkait dengan pajak, ketenagakerjaan, kesehatan, korporasi/badan hukum, transportasi, adat, polusi atau pencucian uang); hal-hal lain diluar perkayuan (penyelesaian akhir, materialmaterial lain, pengepakan) dan beberapa fase produksi (pemanenan, pemuatan, pengiriman, pengolahan, perdagangan dan penggunaan akhir). Secara khusus, pendekatan lebih dalam dapat dilakukan untuk mencapai prosedur pendapatan ijin pengusahaan hutan, termasuk di dalamnya ketaatan untuk perencanaan hukum, persyaratan dalam AMDAL, prosedur tender, persyaratan "keterbukaan" tender dan tidak adanya kecurigaan korupsi dan kolusi.

Sebagai usaha untuk menjauhkan pembelian langsung dari produk yang berasal dari pembalakan liar dan bantuan dari operator legal, perusahaan sangat perlu untuk mengetahui arti dari "legal" atau sumber yang terpercaya. WWF GFTN menyusun dua tingkat pendekatan untuk penetapan dan kelengkapan verifikasi legal (lihat Tabel 1 di bawah). Pendekatan ini disusun untuk memastikan bahwa investasi perusahaan dalam pengawasan legalitas merupakan proporsi resiko dari produk yang mengandung sumber kayu illegal. WWF merekomendasikan bahwa pemasok yang gagal pada kategori resiko rendah (berdasarkan tingkat penilaian 
Tabel 1. Sumber dengan ijin yang dikenali dan kayu legal terverifikasi

\begin{tabular}{|c|c|}
\hline $\begin{array}{l}\text { Pemeriksaan kelengkapan } \\
\text { dasar legalitas }\end{array}$ & $\begin{array}{l}\text { Sumber dengan ijin terkenali } \\
\text { - Pembelimengetahuidimanapohontersebut } \\
\text { tumbuh dan dapat mengidentifikasi pihak } \\
\text { pemanen. } \\
\text { - Pihak pemanen memiliki ijin legal untuk } \\
\text { melakukan pemanenan (memiliki ijin } \\
\text { pemanenan dan wewenang dari pemilik } \\
\text { hutan). } \\
\text { - Rantai pemeliharaan (Chain of Custody) } \\
\text { tidak rusak. }\end{array}$ \\
\hline $\begin{array}{l}\text { Pemeriksaan menyeluruh } \\
\text { terhadap kelengkapan } \\
\text { legalitas }\end{array}$ & $\begin{array}{l}\text { Kayu legal terverifikasi } \\
\text { - Kayu dipanen secara legal. } \\
\text { - Seluruh biaya dibayarkan. } \\
\text { - Kayu diperdagangkan secara legal } \\
\text { (termasuk kelengkapan dalam hukum } \\
\text { CITES). } \\
\text { - Audit kelengkapan legalitas oleh pihak } \\
\text { ketiga dilakukan dan rantai pemeliharaan } \\
\text { (CoC) terverifikasi. } \\
\text { - Memenuhi persyaratan dalam Prinsip } 1.1 \\
\text { dan } 1.2 \text { dari FSC serta pemeriksaan legalitas } \\
\text { impor dan ekspor. }\end{array}$ \\
\hline
\end{tabular}

resiko) untuk diverifikasikan dengan menggunakan pengawasan kelengkapan legalitas dasar. Sumber resiko tinggi memerlukan tingkat analisis yang lebih besar, seperti ditetapkan dalam pengawasan kelengkapan legalitas penuh. Pendekatan ini mengasumsikan bahwa pengawasan legalitas merupakan respon utama untuk permasalahan pembalakan liar dan berdasarkan hal tersebut difokuskan pada kegiatan rantai penyediaan yang terkait dengan pembalakan liar.

Pada penentuan legalitas sumber kayu, kategori dasar dikenal sebagai 'sumber dengan ijinyang diketahui' ('known licensed source). Verifikasi bahwa kayu pada produk perkayuan berasal dari sumber dengan ijin yang melibatkan pengawasan bahwa kayu yang digunakan benar-benar berasal dari unit pengelolaan hutan 
yang memiliki ijin legal untuk melakukan pemanenan. Pada hal ini pembeli sangat perlu untuk (a) mengetahui lokasi geografi dari sumber kayu, dan (b) melakukan konfirmasi bahwa pelaku pemanenan memiliki hak legal untuk kegiatan pemanenan. Hal ini tidak melibatkan proses verifikasi bahwa kayu yang digunakan pada produk perkayuan benar-benar dipanen dan diperdagangkan secara legal. Sebagai contoh, kayu yang digunakan mungkin ditebang dengan melanggar ijin tebang, royalty yang mungkin tidak dibayar, atau kayu yang mungkin diekspor secara illegal. Hal ini juga tidak melibatkan verifikasi pihak ketiga pada rantai pemeliharaan (Chain of Custody - CoC).

Pada kategori kedua, keperluan untuk analisis pada tingkat yang lebih tinggi, dideskripsikan sebagai 'legalitas terverifikasi'. Pada kategori ini pembeli diminta untuk membuktikan bahwa, sebagai bukti kepemilikan ijin legal untuk pemanenan, pihak pemanen melengkapi persyaratan hukum pada saat pemanenan kayu serta ekspor impor kayu secara legal. Kategori ini juga mensyaratkan adanya penelitian pada tingkat yang lebih tinggi mengenai rantai pemeliharaan. WWF merekomendasikan kepada para pembeli untuk melakukan pemeriksaan pada tingkat yang lebih tinggi pada saat kayu illegal dengan resiko yang lebih tinggi memasuki rantai persediaan mereka. Sistem sertifikasi pengelolaan hutan yang memerlukan adanya audit rantai pemeliharaan $(\mathrm{CoC})$ yang independen dapat juga digunakan untuk membuktikan keberadaan kelengkapan legalitasnya.

\subsection{Pembelajaran dari Penentuan Kayu “Legal”}

Peraturan pemerintah dalam verifikasi kayu 'legal' sangat penting dilakukan mengingat pemerintah merupakan pemegang wewenang dalam hal legalitas. Hal ini sekaligus menjadi suatu dilema saat beberapa pihak yang mengajukan sertifikasi biasanya menjadi kurang percaya dengan sistem pemerintahan yang ada. Pemerintah Indonesia membuat hukum-hukum dan peraturan-peraturan untuk mengatur kehutanan di Indonesia. Hukum-hukum tersebut kemudian diaplikasikan dan diinterpretasikan oleh pejabat pemerintah serta institusi pemerintah terkait. Pada langkah selanjutnya, hukum dibidang kehutanan hanya dapat diperbaiki atau disusun ulang oleh legislatif dengan mempertimbangkan masukan dari Departemen Kehutanan serta institusi pemerintah terkait dengan keberadaan areal hutan.

Pada sisi pengaturan, atau non-voluntary, pendekatan oleh institusi publik seperti rencana kegiatan EU FLEGT, yang juga dimotivasi penuh oleh keinginan untuk 
mewujudkan pengelolaan hutan yang lestari, sepertinya akan dihalangi oleh peraturan WTO terkait dengan batas-batas pembebasan tarif. Terkait dengan halangan-halangan tersebut, EU dan anggota individu WTO menyatakan bahwa mereka terpaksa menerima standar legalitas yang dipromosikan oleh pemerintah Indonesia. Sebagai contoh, skema legalitas ijin di dalam rencana kerja EU FLEGT dirancang untuk bekerja dengan legalitas ijin yang dikeluarkan oleh pemerintah dari negara-negara pengekspor.

Pada saat sebuah aturan main untuk auditor pihak ketiga dan verifikasi legalitas sukarela memenuhi persetujuan pemerintah, kondisi ini akan memerlukan sistem yang secara administrasi dikelola oleh pemerintah. Berdasarkan pada hal tersebut, Standar Legalitas sangat penting untuk diadopsi oleh pemerintah.

Kesepakatan mengenai kriteria legalitas menimbulkan pertanyaan sulit bagi hubungan antara petugas pemerintahan dan auditor disamping standar yang ada. Apakah standar yang digunakan murni untuk evaluasi pemenuhan legalitas dalam industri kehutanan, atau hal ini juga digunakan untuk evaluasi apakah hukum yang ada telah diaplikasikan dengan benar oleh petugas pemerintahan terkait? Pada kasus lain, apakah konsekuensi dari temuan bahwa sebuah pelaksanaan pengelolaan hutan yang dicederai oleh sebuah kegagalan/kerusakan penatausahaan/administrasi dalam penerapan/pelaksanaan aturan/hukum? Apabila akibat lain tersebut timbul diluar kontrol dari manajer kehutanan, apakah hal ini berarti bahwa manajer tersebut harus berhenti dan/atau tidak akan dapat menyediakan kayu legal, sampai pihak yang terkait dengan penatausahaan dapat memperbaiki kerusakan tersebut? Status apa yang harus diberikan pemerintah untuk penemuan auditor lepas mengenai para petugas yang melanggar peraturan/ hukum di bidang pemberian ijin yang relevan atau persetujuan tebang. Halhal tersebut di atas adalah pertanyaan sulit yang harus dijawab sebagai proses pengambilan kesimpulan dalam standar legalitas.

Legalitas harus memenuhi satu rangkaian konsep yang panjang dari kewajiban dalam bidang kehutanan dan pembelian kayu. Tidak semua hukum kehutanan bagus; beberapa diantaranya juga buruk, tidak terbuka, atau petugasnya yang korup. Hal ini mengakibatkan pembeli tidak dapat fokus pada legalitas yang dipandang secara baik oleh pihak luar. Mungkin tidak ada satupun HPH di Indonesia yang memenuhi tujuh prinsip dalam draft legalitas standar, dan desakan standar pada penataan batas yang benar (gazettal) mungkin akan mengurangi kemauan sebagian besar $\mathrm{HPH}$ untuk melaksanakan hal tersebut 
pada masa pertengahan kerjanya, meskipun jika mereka sedang melakukan usaha untuk meningkatkan kualitas dari praktek pengelolaan hutan mereka. Proses diskusi mengenai hal tersebut saat ini sedang dilakukan untuk menentukan langkah terbaik dalam hal aplikasi standar, dengan melibatkan para pihak secara proporsional pada pendekatan bertahap untuk mencapai legalitas. 


\title{
5. Pembelajaran Umum
}

\author{
Beberapa kebijakan pemerintah telah berperan sebagai hambatan serius atau \\ dis-insentif bagi perusahaan untuk bergabung dalam program pencapaian \\ pengelolaan hutan lestari. Hal ini secara umum diakui bahwa mekanisme \\ sukarela, seperti sertifikasi dan verifikasi legalitas pihak ketiga independen hanya \\ dapat berperan dalam mencari solusi permasalahan deforestasi dan bahwa campur \\ tangan pemerintah memainkan peran pelengkap yang penting. Bagaimanapun \\ juga, pengalaman dari Aliansi menyarankan bahwa di Indonesia pemerintahan \\ atau lebih luas tata kelola (governance) juga merupakan faktor kritis yang dapat \\ menentukan kesuksesan atau kegagalan dari mekanisme sukarela tersebut.
}

Peraturan-peraturan pada pemanenan dan lalu-lintas kayu di Indonesia sekarang ini sangat tidak teratur, berpihak pada produser skala besar, dan menciptakan peluang korupsi. Proses penyusunan dari keseluruhan perijinan untuk operasional pengusahaan hutan dapat berlangsung lama dan mahal terutama bagi pengelolaan hutan skala kecil. Proses birokrasi yang berbelit telah menciptakan peluang untuk memperoleh pendapatan sampingan, dimana kegiatan ini berpengaruh signifikan pada ongkos produksi kayu, yang bermuara pada lemahnya transparansi dan pemerintahan. Proses desentralisasi kemungkinan telah meningkatkan beban pengaturan ketika proses dari reformasi sesaat telah mengarah pada konflik hukum dan ketidakjelasan tanggung jawab atas aktivitas di sektor kehutanan.

Sebuah perkembangan yang menjanjikan sehubungan dengan mekanisme keterkaitan pasar merupakan hasil dari MoU Bilateral yang terkait dengan FLEG antara pemerintah Indonesia dan pemerintah UK, Cina, Jepang, dan juga skema perijinan legalitas yang diusulkan dibawah inisiatif EU-FLEG. Pengaruh dari perjanjian ini akan tergantung pada kemauan dan kapasitas dari Pemerintah RI untuk mengimplementasikannya. Komponen kunci dari upaya-upaya pemerintah RI adalah sistem administrasi kayu yang dipakai untuk identifikasi pembalakan legal. Sistem yang ada memiliki kelemahan dari aspek kredibilitas di pasar tetapi Dephut sedang mengembangkan sebuah sistem yang diperbaharui yang direncanakan dijalankan pada tahun 2007. 
Pemerintah di negara importir produk kayu dari Indonesia juga memiliki dukungan peran yang penting untuk sertifikasi hutan dan inisiatif verifikasi legalitas di Indonesia. Sektor publik adalah sebuah segmen pasar kayu, dan mendekati 20 persen dari total permintaan kayu di Eropa yang digunakan oleh lembaga pemerintah. Lembaga pemerintah umumnya memerlukan produk kayu yang dapat digunakan untuk proyek-proyek konstruksi publik, dan kemungkinan bahwa sebagian besar dari produk plywood Indonesia dan furnitur murah dijual di pasar EU yang akan juga dipengaruhi oleh kebijakan pengadaan dan pembelian publik. Pemerintah dari negara importir juga mengimplementasikan persetujuan bilateral FLEG dan perjanjian bilateral dan multilateral lainnya yang berdampak pada perdagangan kayu. Aliansi telah menjalin kerjasama erat dengan pemerintah Jepang, Cina dan Eropa.

\section{Permintaan produk hutan lestari tidak secara langsung menjadi sebuah kemauan untuk membayar harga tambahan dari ongkos produksi secara} lestari. Pengalaman Aliansi menunjukkan bahwa pembeli memiliki kemauan untuk membayar harga premium, tetapi hal ini tidak cukup tinggi untuk meyakinkan para pemasok untuk memperoleh sertifikasi. Pengalaman Nusa Hijau dengan PT. Irma Silindo, sebuah HPH di Papua adalah salah satu contoh kasusnya. Perusahaan ini memegang hak konsesi baru yang memproduksi kayu Merbau (Instia bijuga) yang memasok perusahaan furniture outdoor di Sulawesi. PT. Irma Sulindo menunjukkan minat untuk mencapai standar sertifikasi sebagai persyaratan pada para pembeli yang dikoordinir oleh WWF bersedia membayar sekitar US $\$ 1.250 / \mathrm{m}^{3}$ untuk produk bersertifikat. Harga tersebut lebih dari dua kali harga pasar, dimana pembeli seperti itu sulit untuk dicari. Tidak begitu jelas bagaimana tantangan dari PT Irma Sulindo mewakili jumlah harga premium yang dibutuhkan untuk memberi kompensasi para produser di Indonesia yang berinvestasi untuk sertifikasi hutan, tetapi sepertinya secara substansi masih diperlukan harga premium. Fakta anekdot menunjukkan bahwa sebuah harga premium sampai dengan $15 \%$ bahkan telah dibayar oleh para pembeli secara tidak langsung untuk kayu hutan alam yang bersertifikat FSC.

Kehadiran dari sejumlah besar dari kayu illegal yang murah di pasaran barubaru ini membuat kayu yang bersumber legal dan kayu bersertifikat dari FSC sulit untuk berkompetisi. Bagaimanapun juga, jika pembatasan perdagangan kayu illegal dilakukan maka area persaingan menjadi lebih seimbang. Menurut sebuah komisi studi oleh asosiasi American Forest and Paper (AF \& PA) di tahun 2004, terdapat kandungan kayu illegal sekitar 7\% atau sekitar US \$ 5 juta dari 
keseluruhan perdagangan produk kayu primer dunia. Studi ini menghitung adanya penghilangan sumber kayu bulat illegal dari perdagangan kayu dunia yang akan meningkatkan harga antara dua sampai 4 persen dari harga kayu domestik di Amerika Serikat (US).

\section{Untukmeningkatkan pengaruh sertifikasi pada manajemen hutan alam tropika diperlukan peningkatan adopsi dari sebuah pendekatan bertahap (stepwise} approach). Perusahaan yang meminta produk bersertifikat adalah perusahaan yang tidak menginginkan adanya resiko dan mampu untuk memperoleh produk tersebut dari wilayah yang dianggap beresiko lebih bagi citra perusahaannya dari pada Indonesia. Beberapa perusahaan Eropa dan Amerika Utara telah memilih untuk berpindah dari sumber kayu dari Indonesia sehubungan dengan tekanan dari beberapa LSM di negaranya. Seiring dengan banyaknya produk perkayuan Indonesia yang juga diolah di negara lain, beberapa perusahaan menolak mengambil resiko terhadap reputasi perusahaannya dengan hanya mengubah pembeliannya ke negara-negara yang memiliki sedikit kontroversi.

Pemindahan sumber kayu dari sumber kayu yang tidak bersertifikat di Indonesia bukanlah langkah yang baik. Langkah tersebut memberi peringatan kepada para industri, tetapi selama terdapat permintaan terhadap kayu tidak bersertifikat dari pasar maka pesan tersebut tidak berarti banyak untuk menekan perusahaan untuk memperoleh sertifikasi. Pengalaman WWF telah menunjukkan bahwa perusahaan di Indonesia seringkali memiliki kekurangan kapasitas teknik maupun finansial untuk mencapai sertifikasi secara mandiri, meskipun mereka berkeinginan untuk melaksanakannya. Berdasarkan pada hal tersebut, paling tidak dalam jangka pendek, pengaruh dari boikot terhadap sebagian besar dari produk kayu Indonesia yang tidak bersertifikat kemungkinan tidak akan memiliki dampak positif terhadap manajemen hutan di Indonesia.

Ketika para pembeli mengalihkan pembeliannya dari kayu tidak bersertifikat Indonesia, dampak positif dari sertifikasi tidak secara langsung berimbas pada wilayah lain. Pada beberapa kasus pengalihan ini sepertinya dilakukan untuk kayu yang tidak tersubstitusi. Hal ini khususnya kasus untuk plywood yang telah kehilangan pangsa pasar global karena tergantikan oleh produk plastik dan metal. Pada beberapa kasus, karena sedikitnya persediaan jumlah kayu tropis yang bersertifikat dari hutan alam di pasar global, para pembeli bergeser ke produk hutan tanaman bersertifikat dari wilayah lain atau sumber kayu yang berasal dari hutan temperate. Pada kedua kasus tersebut, keuntungan langsung dari sertifikasi 
menjadi lebih kecil dari pada di hutan alam tropika. Perpindahan ke wilayah dan tipe hutan dimana sertifikasi lebih mudah diperoleh dan lebih murah telah mengurangi dampak dari sertifikasi yang sebagaimana terdapat sedikit perbedaan dalam kasus-kasus ini antara sistem manajemen hutan sehari-hari (business as usual) dan yang mengikuti kaidah sertifikasi. Pada akhirnya hal kecil yang dapat dicapai oleh perusahaan melalui pemindahan tersebut adalah penyelamatan reputasi perusahaan.

Terkait dengan hal tersebut di atas, perusahaan-perusahaan yang bermaksud untuk membuat sebuah dampak positif pada lingkungan melalui mekanisme pembeliannya harus bergabung dengan Produser Indonesia dan menekan mereka agar meningkatkan kualitas manajemennya. WWF dan TNC telah beberapa kali sukses membantu beberapa pembeli produk kayu dari Indonesia untuk bekerja sama dengan pemasok Indonesia untuk membantu agar memenuhi standar hutan lestari. Namun, pada beberapa pembeli, ajakan terhadap supliernya Indonesia mungkin memerlukan investasi lebih besar dari kemauan dan kemampuannya, apalagi fakta menunjukkan bahwa pasar untuk produk subtitusi kayu seringkali lebih murah. Pada beberapa kasus, kerugian terbesar dari perusahaan yang bekerjasama dengan perusahaan yang tidak tersertifikasi adalah bahwa hal tersebut tidak akan memperbaiki hubungan baik dengan LSM-LSM di negaranya karena para LSM tersebut seringkali memiliki sebuah kebijakan "Sertifikasi atau tidak Sertifikasi”. WWF berencana untuk meningkatkan upayanya untuk menjelaskan kepada para NGO tersebut mengenai keuntungan dari pendekatan bertahap (stepwise approach) menuju sertifikasi.

\section{Perusahaan yang sensitif terhadap lingkungan memiliki kepedulian yang tinggi akan citra perusahaannya, dan memerlukan jaminan bahwa produk yang mereka beli disetujui oleh para aktivis LSM di pasar negaranya.} Pengalaman dari Aliansi menunjukkan pentingnya dukungan LSM sebagai dasar inisiatif pasar. Permintaan untuk kayu bersertifikat dari Indonesia sebagian besar didorong oleh tekanan dari LSM terhadap perusahaan di Eropa dan Amerika Utara. Pada hal yang sama, terhentinya pasokan produk dari Indonesia dipengaruhi oleh tingkat kesepakatan LSM lokal dan nasional mengenai sertifikasi dan verifikasi legalitas. Kurangnya dukungan LSM secara umum pada mekanisme ini menjadi salah satu faktor yang menghalangi perusahaan untuk memenuhi permintaan pasar. Sebagai konsekuensi dari hal tersebut, pembangunan dukungan merupakan aktivitas penting yang dilakukan oleh Aliansi. 
Aktivis lingkungan memainkan peran penting dalam hal permintaan pasar untuk kayu legal dan bersertifikat di Eropa dan Amerika Utara. Pada pasar tersebut, LSM-LSM memiliki pengaruh penting terhadap pembeli kayu dan para pembuat kebijakan pemerintah. Perusahaan terkenal, seperti dalam Do-ItYourself (DIY) industri konstruksi berharap untuk membuat dan memelihara reputasi lingkungannya melalui praktek bisnis yang bertanggung jawab terhadap lingkungan. Aktivis LSM memberikan tekanan kepada perusahaan-perusahaan tersebut melalui kampanye dengan menggunakan media kepada sebuah perusahaan tertentu yang terkait dengan pembalakan tidak lestari atau pembalakan liar.

LSM yang melakukan penekanan terhadap perusahaan untuk hanya membeli kayu dari sumber yang lestari, juga efektif digunakan untuk menentukan kayu mana yang memenuhi persyaratan dan yang tidak. Hal ini mengakibatkan jaringan pasar di Indonesia menjadi sulit, karena adanya keterlibatan dari LSM nasional yang memiliki jaringan ke LSM di pasar perkayuan, dan mendorong adanya boikot terhadap produk perkayuan Indonesia hingga terwujudnya penataan ulang di bidang kehutanan. Beberapa LSM Indonesia percaya bahwa dengan sistem $\mathrm{HPH}$ yang sekarang ini, pengelolaan hutan yang lestari tidak mungkin dilakukan dan usaha untuk mengenalkan sertifikasi atau verifikasi legalitas pada pasar dapat menghalangi penataan ulang di bidang kehutanan dalam skala luas. LSM seperti WALHI dan AMAN merupakan LSM yang memberikan perhatian penuh dalam hal hak penggunaan lahan secara tradisional pada hutan kemasyarakatan.

Contoh ilustrasi dari pengaruh LSM pada jaringan pemasaran diberikan oleh TNC melalui pengalaman kerja sama dengan Sumalindo. Meskipun perusahaan ini telah memiliki sejarah panjang di bidang sertifikasi, perusahaan ini menjadi target dari kampanye Greenpeace pada Juni 2003. Berdasarkan informasi yang diberikan oleh koalisi LSM Indonesia, Kelompok Kerja Kalimantan Timur (East Kalimantan Working Group- EKWG), Greenpeace telah mengidentifikasi Sumalindo sebagai salah satu pemasok plywood ke bidang konstruksi di pemerintahan Inggris, dan meningkatkan perhatiannya dalam bidang operasional perusahaan. EKWG juga mencatat bahwa Sumalindo merupakan perusahaan yang secara tidak langsung dimiliki oleh militer Indonesia. ${ }^{33}$ Pernyataan ini menjadi perdebatan, tetapi tidak mencegah rusaknya reputasi Sumalindo di pasar Eropa.

Implikasi dari strategi Aliansi untuk mengikat perusahaan perkayuan adalah bahwa Aliansi pada beberapa sisi memiliki posisi sebagai pelindung antara perusahaan

${ }^{33}$ EKWG 2003. 
untuk mendapatkan sertifikasi dan LSM yang menjadi oposisi pada usaha-usaha yang dilakukan. Merujuk pada Perhutani, keuntungan terbesar dalam bekerja sama dengan WWF Nusa hijau adalah bahwa WWF dapat melindungi perusahaan tersebut dari serangan LSM. Manajemen Perhutani memiliki kesan bahwa alasan yang digunakan oleh Smartwood untuk mencabut sertifikasi yang diberikan oleh FSC pada tahun 2002 terkait dengan adanya tekanan dari LSM nasional. Melalui kerjasama dengan WWF, Perhutani berharap agar hal tersebut tidak terjadi lagi dikemudian hari. ${ }^{34}$

WWF dan TNC tidak menyatakan bahwa merupakan kewajiban mereka untuk melindungi perusahaan-perusahaan dari kampanye LSM dan pada beberapa kasus menggunakan tekanan dari para aktivis LSM sebagai kekuatan positif untuk melakukan perubahan di bidang kehutanan. Hal ini juga terkait dengan pertanyaan mereka mengenai hak untuk saling mengkritisi antara organisasi satu dengan yang lain, atau untuk bertahan dan berargumentasi dari kritikan LSM. Keanggotaan GFTN mensyaratkan perusahaan untuk membuat suatu komitmen yang jelas mengenai kewajiban di bidang kehutanan, termasuk di dalamnya target waktu pencapaian sertifikasi lebih lanjut, atau mengurangi dan menghilangkan sumber kayu yang tidak jelas dan yang tidak diinginkan. Penggunaan sistem lacak balak, seperti yang dicontohkan oleh TNC, juga dapat mendukung perusahaan dalam menghadapi tuntutan mengenai keterlibatannya dalam penggunaan kayu illegal.

\section{Untuk mencapai sukses, mekanisme berbasis pasar memerlukan tindakan} nyata dan menyeluruh, dari pasar utama. Produk perkayuan Indonesia memiliki pasar yang bersifat global, dan adanya pilihan pembelian dari pasar Eropa dan Amerika Utara hanya akan menimbulkan akibat minimum bagi para produsen Indonesia, selama mereka masih memiliki akses ke pasar dengan tingkat kepedulian lingkungan yang lebih rendah. Kondisi tersebut memerlukan ikatan jangka panjang terhadap pasar Asia untuk produk perkayuan Indonesia, khususnya Cina, Jepang, Malaysia dan Republik Korea. Usaha untuk mempromosikan mekanisme berbasis pasar juga perlu mempertimbangkan kompleksitas permasalahan dan seringkali juga terkait dengan jaringan penyediaan (supply chain), pada skala internasional. Sebagai contoh, banyak produk perkayuan Indonesia yang masuk ke Cina yang diindikasikan di ekspor kembali ke Eropa dan Amerika Utara dengan tambahan pemrrosesan kayu dengan kualitas yang lebih baik.

${ }^{34}$ Perhutani staff, personal communication. 


\section{Adanya peningkatan iklim politik dan bisnis telah mendorong usaha di bidang pemasaran untuk peningkatan pengelolaan hutan di Indonesia. Pada saat} Aliansi menyusun promosi sertifikasi di Indonesia untuk pertama kali, pendekatan yang dilakukan adalah dengan menggunakan asumsi yang menempatkan pembeli potensial dari produk yang memiliki sertifikat dengan para pengelola $\mathrm{HPH}$, akan memberikan insentif lebih kepada pemegang pengusahaan untuk mendapatkan sertifikasi. Pada kenyataannya permasalahan yang dihadapi menjadi lebih sulit seiring dengan adanya rintangan yang cukup berarti bagi para produsen untuk mendapatkan sertifikasi di Indonesia. Sebagian besar rintangan tersebut terkait dengan kesenjangan kondisi yang memerlukan waktu untuk mengubahnya, dan berada diluar kontrol pembeli dan produsen kayu itu sendiri. Meskipun demikian, perubahan terus terjadi dan mekanisme pasar potensial seperti sertifikasi akan memainkan peranan yang lebih besar dalam bidang kehutanan di Indonesia pada masa yang akan datang.

Halangan utama pada adopsi sertifikasi di Indonesia adalah ketidakpastian dalam iklim usaha yang mengancam investasi jangka panjang. Aliansi mulai melakukan kegiatannya pada saat Indonesia baru saja mengalami permasalahan finansial dan krisis politik yang berdampak besar pada sektor kehutanan. Krisis ekonomi makro ini dilengkapi dengan adanya praktek penebangan yang dilakukan secara tidak lestari yang dilakukan sebagai usaha untuk memenuhi kebutuhan bahan baku bagi sebagian besar industri perkayuan di Indonesia. Indonesia masih berada pada posisi perbaikan dan sedang melakukan usaha-usaha untuk melakukan restrukturisasi industri perkayuan. Selama proses tersebut berlangsung, hal yang harus diingat adalah bahwa perusahaan pengusahaan hutan dan pengolahan kayu akan mendapatkan kapasitas yang lebih besar untuk melakukan investasi di bidang kelestarian hutan.

Ketidakseimbangan arena permainan (playing field) yang meningkatkan biaya bagi perusahaan pengusahaan hutan untuk mendapatkan kesempatan dalam sertifikasi mungkin dapat disamakan. Departemen Kehutanan telah membuat suatu kesepakatan yang cukup jelas untuk mengurangi pembalakan liar dan menyatakan untuk meniadakan penggunaan kayu dari hutan alam (MTH) untuk produksi pulp pada tahun 2009 mendatang. Melalui masukan dari TNC, Departemen Kehutanan sedang melakukan sistem lacak balak yang diharapkan dapat berfungsi dan digunakan pada beberapa tahun mendatang. Reformasireformasi di bidang pemerintahan ini secara umum dipicu oleh tekanan dari pembeli untuk mengurangi jumlah kayu 'tebang dan lari' di pasar. Pada jangka 
menengah, beberapa hasil pembaharuan tersebut akan mengurangi adanya kesenjangan antara standar praktek pengelolaan hutan dan persyaratan yang diberikan oleh FSC untuk sertifikasi.

Beberapa perusahaan yang tidak memenuhi persyaratan sertifikasi FSC karena kondisinya di masa lalu (contoh: melakukan konversi hutan alam untuk perkebunan di tahun 1994) melakukan investasi pada pendekatan untuk verifikasi legalitas dengan kombinasi deliniasi dan perlindungan HCVF dengan pola "yang terbaik di masa mendatang". APP dan APRIL sebagai perusahaan kertas terbesar di Indonesia mendapatkan peningkatan tekanan dari pembeli di Eropa, Australia, Amerika Serikat dan Jepang untuk melakukan investasi di bidang kelestarian hutan. Pada saat perusahaan-perusahaan tersebut tidak dapat memenuhi persyaratan sertifikasi FSC karena mereka terus melakukan konversi terhadap hutan alam, mereka telah melakukan berbagai usaha untuk bekerja sama dengan LSM, termasuk WWF, untuk mengurangi penggunaan kayu illegal dan melakukan identifikasi HCVF hutan untuk fungsi perlindungan. 


\section{Rekomendasi}

1. Menjaga pembeli yang sensitif terhadap isu lingkungan untuk tetap berhubungan dengan produsen perkayuan Indonesia merupakan kegiatan penting dari TNC dan WWF yang mungkin akan terus dilakukan. Hal ini mungkin memerlukan identifikasi lebih lanjut mengenai pembeli produk perkayuan Indonesia dan kerjasama untuk menempatkan tekanan dari pemasok mereka untuk melakukan investasi di SFM, atau untuk mencapai sertifikasi hutan.

2. Bagi pembeli yang melakukan pencarian jaringan pasar sebagai bagian dari usaha untuk promosi investasi di bidang SFM, harus memenuhi kriteria sebagai berikut:

- Harga dan jumlah barang cukup memenuhi kompensasi untuk biaya investasi.

- Kesepakatan pembelian untuk jangka panjang.

- Kesepakatan yang dilakukan berdasarkan hubungan personal atau garansi/jaminan lain yang berlaku bagi produsen Indonesia.

- Kesepakatan yang menjamin outlet dari seluruh jaringan produksi.

3. Strategi yang harus diperhatikan oleh Aliansi untuk meningkatkan pencarian pasar, mungkin dilakukan dengan bekerja lebih dekat dengan perusahaan untuk menemukan tipe kesepakatan yang dapat memicu mereka untuk melakukan investasi di bidang SFM. Sebagai usaha untuk membuat pasar yang lebih terintegrasi, Aliansi dapat bekerja lebih fokus dengan broker atau perantara kayu besar yang dapat melakukan pengumpulan permintaan.

4. Usaha-usaha dalam penentuan standar legalitas perlu melibatkan kompleksitas dari kerangka legalitas kehutanan di Indonesia untuk mengajak perusahaanperusahaan yang memiliki kesadaran untuk berpartisipasi dalam pendekatan legalitas dan sertifikasi. Kesalahan prosedur perijinan oleh para petugas pemerintahan di masa lampau menempatkan beberapa $\mathrm{HPH}$ pada posisi legalitas yang sulit yang tidak memungkinkan untuk melakukan perubahan. 
5. Aliansi sebaiknya melanjutkan bekerja pada bidang kebijakan untuk mendorong terwujudnya hukum dan peraturan yang mendukung inisiatif FLEG. Pada bagian lain, usaha-usaha harus dilakukan di Jepang dan Amerika Serikat.

6. Permintaan pasar yang mempengaruhi pengelolaan hutan di Indonesia merupakan hal yang kritis. Berdasarkan pada hal tersebut, sangat perlu untuk terus memfokuskan pada pasar Asia secara umum untuk produk perkayuan Indonesia termasuk Cina, Malaysia, Republik Korea dan Jepang. Sebagai bagian dari hal ini, sangat diperlukan adanya analisis lebih lanjut mengenai ekspor ulang terhadap produk perkayuan Indonesia dari Cina ke pasar Eropa dan Amerika Utara. 


\section{Bibliografi}

AF\&PA 2004. Illegal Logging and Global Wood Markets: The Competitive Impacts on the US Wood Products Industry. American Forest \& Paper Association, Seneca Creek Associates and Wood Resources International, November. (http://www.illegallogging. info/papers/afandpa.pdf).

Barbier, E., Burgess, J., Bishop, J. dan Aylward, B. 1994. The Economics of the Tropical Timber Trade. Earthscan, London.

Blandon, P. 1999. Japan and World Timber Markets. CABI Publishing.

Burrows, J. dan Sanness, B. (ed.) 1998. The Competitive Climate for Wood Products and Paper Packaging: The Factors Causing Substitution, with Emphasis of Environmental Promotions. UNCECE/FAO, Oslo.

Cashore, B., Auld, G., dan Newsom, D. 2004. Governing Through Markets, Forest Certification and the Emergence of Non-State Authority. Yale UP, New Haven.

EKWG 2003. A Study on FSC Certification and the Sumalindo Company in East Kalimantan. East Kalimantan Working Group on Forests.

Virgilio, V., Jamison, E., Donovan, R., Elliot, C. dan Gholz, H. (ed.) 1996. Certification of Forest Products, Issues and Perspectives. Island Press, Washington D.C.

Chunquan, Z., Taylor R. dan Guoqiang F. 2004. China's Wood Market, Trade and the Environment. Science Press and WWF International.

Colchester, M., Sirait, M. dan Wijardjo, B. 2003 Implementation of FSC principles.

Eba'a Atyi, R. dan Simula, M. 2002. Forest Certification: Pending Challenges for Tropical Timber. Background Paper. ITTO International Workshop on Comparability and Equivalence of Forest Certification Schemes, Kuala Lumpur, 3-4 April, 2002.

Gale, F. 1998. The Tropical Timber Trade Regime. Macmillan Press Ltd, London.

Grainger, A. 1993. Controlling Tropical Deforestation. Earthscan, London.

ITTO 1999. Report On The Impediments To Market Access For Tropical Timber.

Prepared by Tan Sri Dato' Wong Kum Choon and J. Michael Ginnings. 
ITTO. 2003. "Reviving Plywood". In Tropical Forest Update. March 13, 2003.

Lu Wenming, et al. 2002. Getting the private sector to work for the public good: instruments for sustainable private sector forestry in China. Stevenage, Hertfordshire : Earthprint.

Mir and Fraser 2003. Illegal logging in the Asia-Pacific region: an ADB perspective. International Forestry Review 5, 278-281.

Peck, T. 2001. The International Timber Trade. Woodhead Publishing, Cambridge.

RIIA 2002. Controlling the International Trade In Illegally Logged Timber And Wood Products. Duncan Brack, Kevin Gray and Gavin Hayman. Royal Institute for International Affairs, Chatham House, London.

RIIA 2004. FLEGT and Trade - What Will the Impacts Be? Royal Institute for International Affairs, Chatham House, London.

RIIA 2004b. Public Procurement Of Timber; EU member state initiatives for sourcing legal and sustainable timber, by Duncan Brack and Jade Saunders. Royal Institute for International Affairs, Chatham House, London.

Robbins, P. 1995. Tropical Commodities and their Markets. Kogan Page Ltd. London.

Simula, M.; Eba'a Atyi, R. \& Nussbaum, R. 2003. The Potential Role of Phased Approaches to Certification on Tropical Timber Producer Countries as a Tool to Promote Sustainable Forest Management. ITTO.

UNECE/FAO 2005. Forest Products Annual Market Review 2004-2005. Timber Bulletin - Volume LVIII (2005). United Nations, Geneva.

A. White, X. Sun, K. Canby, J. Xu, C. Barr, E. Katsigris, G. Bull, C. Cossalter, dan S. Nilsson. 2006. China and the Global Market for Forest Products: Trends, Implications, and Steps to Transform the Trade to Benefit Forests and Livelihoods, Washington D.C.: Forest Trends, Center for International Forestry Research, and Chinese Center for Agricultural Policy.

WWF 1995. Dudley, N., Jeanrenaud, J.-P., Sullivan, F. 1995. Bad Harvest? The Timber Trade and the Degradation of the World's Forests. Earthscan, London.

Yeom, Freezaillah B.C. 1984. Lesser-known tropical wood species: How bright is their future? in Unasylva - No. 145 Vol. 36 1984/3. 
Center for International Forestry Research (CIFOR) adalah lembaga penelitian kehutanan internasional terdepan, yang didirikan pada tahun 1993 sebagai tanggapan atas keprihatinan dunia akan konsekuensi sosial, lingkungan dan ekonomi yang disebabkan oleh kerusakan dan kehilangan hutan. Penelitian CIFOR ditujukan untuk menghasilkan kebijakan dan teknologi untuk pemanfaatan dan pengelolaan hutan yang berkelanjutan, dan untuk meningkatkan kesejahteraan masyarakat di negaranegara berkembang yang bergantung kepada hutan tropis untuk kehidupannya. CIFOR adalah salah satu di antara 15 pusat yang didukung oleh Consultative Group on International Agricultural Research (CGIAR). Berpusat di Bogor, Indonesia, CIFOR mempunyai kantor regional di Brazil, Burkina Faso, Kamerun dan Zimbabwe, dan bekerja di lebih dari 30 negara di seluruh dunia.

\section{Donatur}

CIFOR menerima pendanaan dari pemerintah, organisasi pembangunan internasional, yayasan swasta dan organisasi regional. Pada tahun 2005, CIFOR menerima bantuan keuangan dari Australia, Asian Development Bank (ADB), Belgia, Brazil, Canada, China, Centre de coopération internationale en recherche agronomique pour le développement (CIRAD), Cordaid, Conservation International Foundation (CIF), European Commission, Finland, Food and Agriculture Organization of the United Nations (FAO), Ford Foundation, France, German Agency for Technical Cooperation (GTZ), German Federal Ministry for Economic Cooperation and Development (BMZ), Indonesia, International Development Research Centre (IDRC), International Fund for Agricultural Development (IFAD), International Tropical Timber Organization (ITTO), Israel, Italy, The World Conservation Union (IUCN), Japan, Korea, Netherlands, Norway, Netherlands Development Organization, Overseas Development Institute $(\mathrm{ODI})$, Peruvian Secretariat for International Cooperation (RSCl), Philippines, Spain, Sweden, Swedish University of Agricultural Sciences (SLU), Switzerland, Swiss Agency for the Environment, Forests and Landscape, The Overbrook Foundation, The Nature Conservancy (TNC), Tropical Forest Foundation, Tropenbos International, United States, United Kingdom, United Nations Environment Programme (UNEP), World Bank, World Resources Institute (WRI) dan World Wide Fund for Nature (WWF). 
ISBN 979-24-4661-3

|| |||||||||||| |||||

IIIIII) 